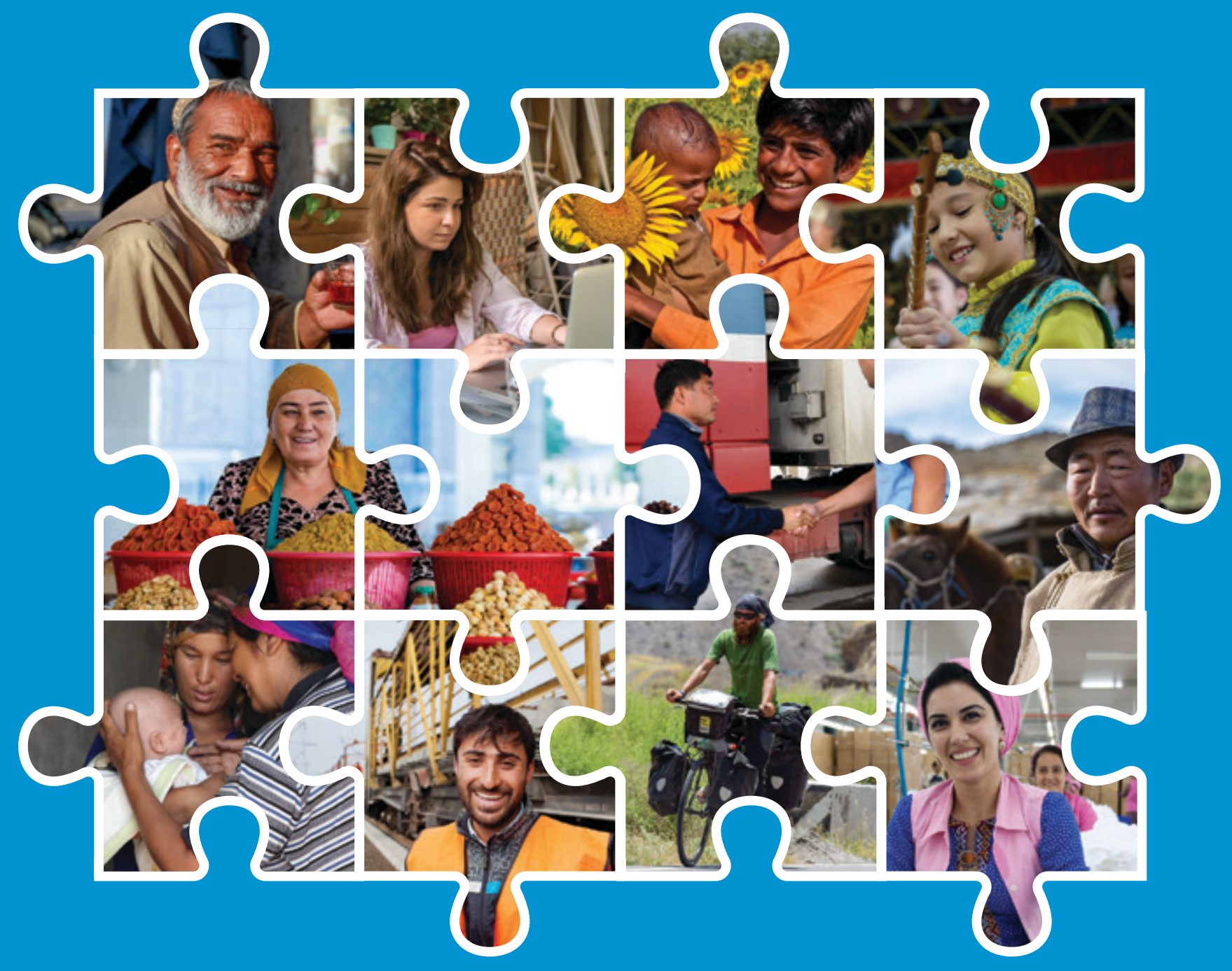

УСИЛЕНИЕ ТРАНСГРАНИЧНОГО

СОТРУДНИЧЕСТВА СООБЩЕСТВ

В РЕГИОНЕ ЦАРЭС

ОБЗОРНОЕ ИССЛЕДОВАНИЕ

Декабрь 2020 г. 



\section{УСИЛЕНИЕ ТРАНСГРАНИЧНОГО СОТРУДНИЧЕСТВА СООБЩЕСТВ В РЕГИОНЕ ЦАРЭС ОБЗОРНОЕ ИССЛЕДОВАНИЕ}

Декабрь 2020 г. 
() 2020 Азиатский банк развития

6 ADB Avenue, Mandaluyong City, 1550 Metro Manila, Philippines

Tel +63 28632 4444; Fax +63286362444

www.adb.org

Некоторые права защищены. Опубликовано в 2020 году.

ISBN 978-92-9262-100-1 (печатный вариант); 978-92-9262-101-8 (электронный вариант); 978-92-9262-102-5 (электронная книга) Номер тиража: TCS200343-3

DOI: http://dx.doi.org/10.22617/TCS200343-3

Изложенные в данной публикации взгляды выражают мнение авторов и могут не совпадать с мнениями и политикой Азиатского банка развития (АБР) или его Совета управляющих, а также правительств тех стран, которые они представляют.

АБР не гарантирует точность данных, содержащихся в настоящей публикации, и не несет ответственность за какие-либо последствия их использования. Упоминание конкретных компаний или продуктов изготовителей не означает, что они одобряются или рекомендуются АБР в качестве предпочтительных, по сравнению с другими подобными продуктами, которые не были упомянуты.

Использование каких-либо обозначений или ссылок на конкретную территорию или географическую зону, равно как и использование в настоящем документе термина "страна", не означает выражение позиции АБР относительно правового или иного статуса такой территории или зоны.

Данный материал доступен на условиях лицензии Creative Commons Attribution 3.0 IGO (CC BY 3.0 IGO) https://creativecommons.org/licenses/by/3.0/igo/. Использование Вами содержания данной публикации означает Ваше согласие соблюдать условия указанной лицензии. Для получения ссылок на источник, переводов, адаптаций и разрешений, пожалуйста, предварительно ознакомьтесь с положениями и условиями пользования на https://www.adb.org/termsuse\#openaccess.

Вышеозначенная лицензия СС не распространяется на содержащиеся в данной публикации материалы, не защищенные авторскими правами АБР. Если материал относится к другому источнику - пожалуйста, свяжитесь с владельцем авторских прав или издателем этого источника для получения разрешения на его воспроизведение.

АБР не может привлекаться к ответственности в связи с какими-либо претензиями, вытекающими из использования Вами таких материалов.

Если у Вас имеются вопросы или комментарии в отношении содержания, либо если Вы желаете получить разрешение владельца авторских прав на использование публикации в целях, не предусмотренных настоящими условиями, или разрешение на использование логотипа АБР, пожалуйста, свяжитесь с pubsmarketing@adb.org.

С исправленными опечатками в публикациях АБР можно ознакомиться по ссылке: http://www.adb.org/publications/corrigenda

Примечания: В данной публикации символом “\$” обозначены доллары США.

АБР признает «Китай» как Китайскую Народную Республику, «Кыргызстан» как Кыргызскую Республику, а «Россию» - как Российскую Федерацию.

Дизайн обложки: Лаура Искьердо и Джозеф Раймунд К. Илумин. 


\section{Содержание}

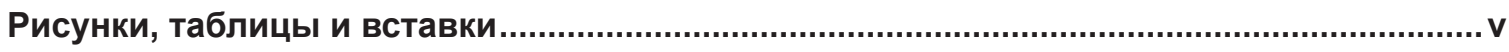

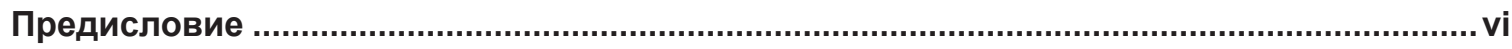

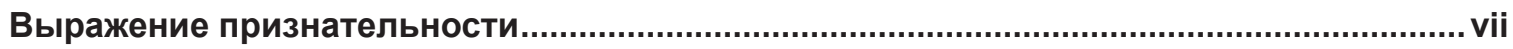

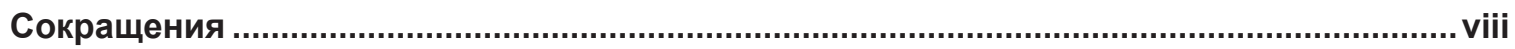

Исполнительное резюме ............................................................................................. ix

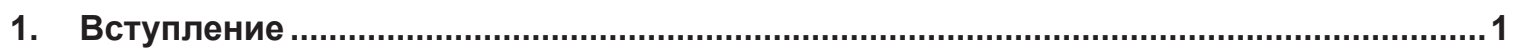

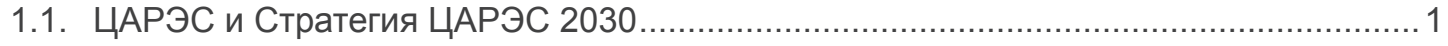

1.2. Цель, методология и структура обзорного исследования …................................. 2

1.3. Подход к взаимодействию между людьми, приграничными и трансграничными

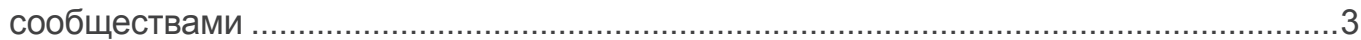

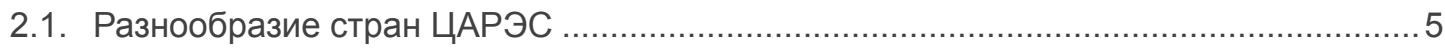

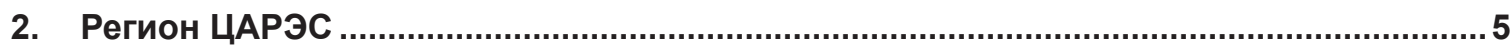

2.2. Барьеры на пути развития трансграничных сообществ и расширения контактов

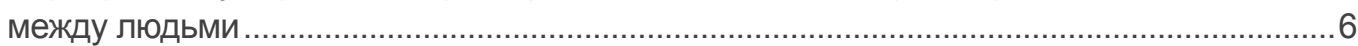

2.3. Женщины в приграничных сообществах ЦАРЭС ...............................................

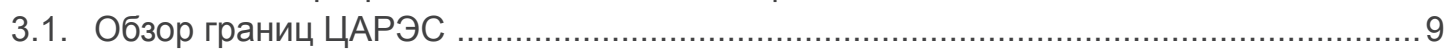

3. Текущее состояние приграничного сотрудничества сообществ в регионе ЦАРЭС.......9

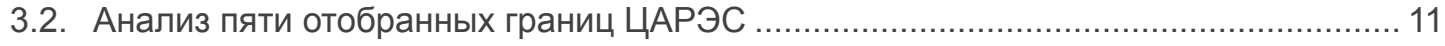

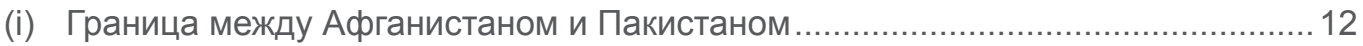

(ii) Граница между Афрганистаном и Таджикистаном ............................................... 14

(iii) Граница между Азербайджаном и Грузией ...................................................... 15

(iv) Граница между Китайской Народной Республикой и Монголией........................ 17

(v) Ферганская долина: Кыргызская Республика, Таджикистан и Узбекистан ........ 19

3.3 Ключевые выводы из анализа границ ЦАРЭС .......................................................2 21

4. Передовой международный опыт сотрудничества приграничных сообществ ..... 22

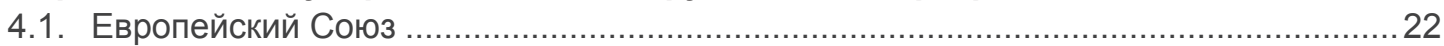

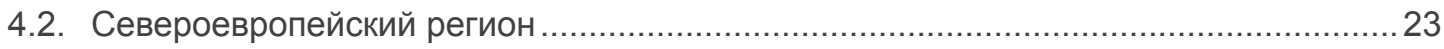

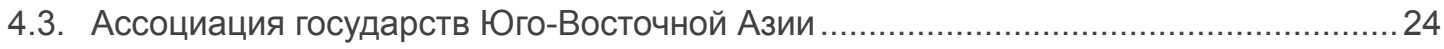

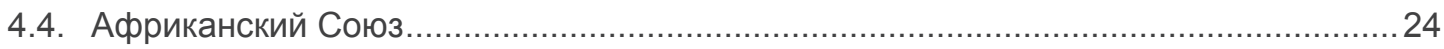


5. Анализ сильных и слабых сторон, возможностей и угроз.....................................25

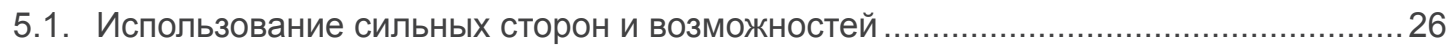

(i) Использовать позитивные региональные тенденции .........................................2 27

(ii) Принять подход, основанный на инициативе сообществ ...................................2 27

(iii) Опираться на рекомендации других исследований ЦАРЭС ….........................2 27

(iv) Развивать цепочки добавленной стоимости в сельском хозяйстве и

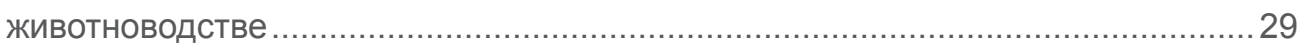

(v) Усилить роль частного сектора и гражданского общества ..................................30

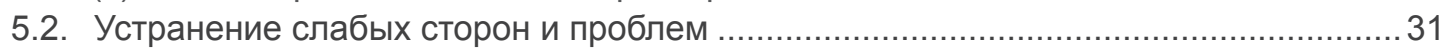

(i) Продвижение приграничных и трансграничных рынков в приграничных

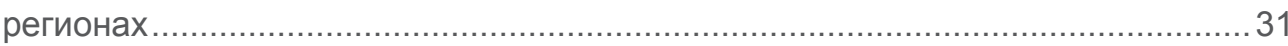

(ii) Увеличение участия микро-, малых и средних предприятий............................ 32

(iii) Решение проблемы воздействия изменения климата на приграничные сообщества

(iv) Усиление роли женщин в развитии приграничных сообществ..........................33

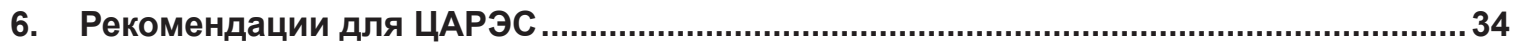

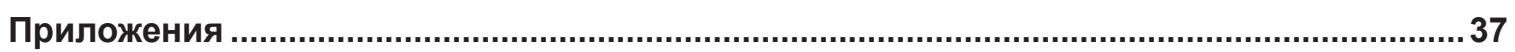

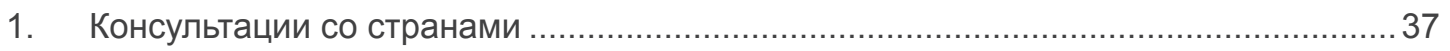

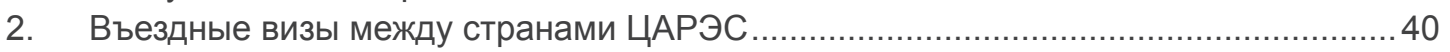

3. Основные пункты пропуска через границу между странами ЦАРЭС ..................... 41

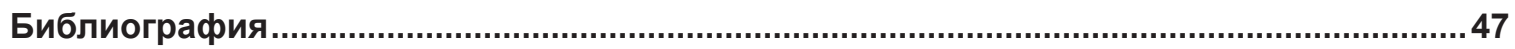




\section{Рисунки, таблицы и вставки}

\section{Рисунок}

1 Доля населения стран ЦАРЭС, живущего ниже национальной черты бедности...... 6

\section{Таблицы}

1 Пограничные пункты пропуска между странами ЦАРЭС....................................... 10

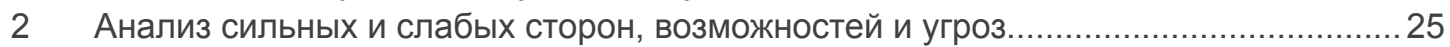

3 Краткое изложение рекомендаций по развитию приграничных сообществ.............34

\section{Вставка}

1 Глубокие культурные связи между афганцами и пакистанцами

2 Приграничный рынок Ишкашим: «Ничейная земля» между Афганистаном и

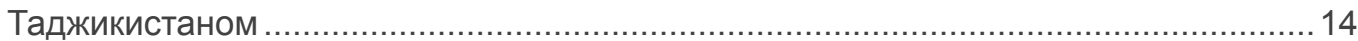

3 Трансграничный туристический маршрут между Азербайджаном и Грузией.......... 16

4 Неформальная экономика на кыргызско-таджикской и кыргызско-узбекской

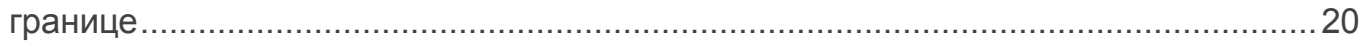

5 Совместное использование воды и пастбищ на кыргызско-таджикской границе ...21 


\section{Предисловие}

Программа Центральноазиатского регионального экономического сотрудничества (ЦАРЭС) - это партнерство 11 стран: Афрганистана, Азербайджана, Китайской Народной Республики, Грузии, Казахстана, Кыргызской Республики, Монголии, Пакистана, Таджикистана, Туркменистана и Узбекистана, а также партнеров по развитию, работающих вместе для содействия развитию посредством сотрудничества, ведущего к ускоренному экономическому росту и сокращению бедности.

Стратегия ЦАРЭС 2030 была одобрена на 16-й Министерской конференции в октябре 2017 года и ознаменовала новую эру для программы до 2030 года. Она предусматривает миссию по объединению людей, политик и проектов для совместного и устойчивого развития, выступая в качестве главной экономической и социальной платформы сотрудничества для региона. ЦАРЭС выборочно расширила свои операционные приоритеты в рамках новой стратегии, чтобы лучше удовлетворять потребности развития региона и помочь своим странам-членам добиться выполнения Глобальной повестки дня в области развития на период до 2030 года.

Некоторые страны-члены ЦАРЭС испытали высокий экономический рост, однако развитие в регионе ЦАРЭС было неравномерным. Перед регионом стоит множество политических, экономических, социальных и экологических проблем, которые напрямую влияют на граждан и сообщества. Для дальнейшего расширения возможностей в регионе и реализации его потенциала для непрерывного экономического роста в целом страны-члены ЦАРЭС должны работать как единое сообщество для решения этих общих и взаимосвязанных проблем. Расширение контактов между людьми в странах региона и содействие сотрудничеству между трансграничными сообществами, молодежью, женщинами и малыми и средними предприятиями будет способствовать устойчивому росту региона.

Это исследование оценивает текущую динамику сотрудничества приграничных сообществ в регионе ЦАРЭС и определяет возможности для продвижения развития сообществ и контактов между людьми. 


\section{Выражение признательности}

Настоящее исследование было проведено Секретариатом Центральноазиатского регионального экономического сотрудничества (ЦАРЭС) и Азиатским банком развития. Команда хотела бы поблагодарить Вернера Липаха, генерального директора Департамента Центральной и Западной Азии, и Сафдара Парвеза, директора Отдела регионального сотрудничества и координации операций Департамента Центральной и Западной Азии, за общее руководство.

Секретариат ЦАРЭС в Азиатском банке развития руководил подготовкой этого предварительного исследования. В команду Секретариата, поддерживающую работу по приграничным сообществам ЦАРЭС, входят Саад Парача, старший специалист по региональному сотрудничеству и руководитель подразделения ЦАРЭС; Лаура Искьердо, специалист по региональному сотрудничеству; и Ирэн С. де Рома, эксперт по программам. Команда также хотела бы выразить благодарность Гуоляну Ву, главному специалисту по управлению результатами, который был главой подразделения ЦАРЭС, когда была начата работа над этим исследованием.

Группа выражает признательность координаторам регионального сотрудничества и советникам национальных координаторов из всех стран ЦАРЭС за помощь, оказанную в сборе соответствующей информации из их соответствующих стран.

Основным автором этого исследования является Харис К. Хан, который продолжил работу, начатую Первизом Ахмедом. 


\section{Сокращения}

\begin{tabular}{|c|c|}
\hline АБР & Азиатский банк развития \\
\hline AKDN & Сеть развития Ага Хана \\
\hline ACEAH & Ассоциация государств Юго-Восточной Азии \\
\hline $\mathrm{AC}$ & Афрриканский союз \\
\hline ЦАРЭС & Центральноазиатское региональное экономическое сотрудничество \\
\hline $\mathrm{OO}$ & общественная организация (организация гражданского общества) \\
\hline EAPTC & Программа территориального сотрудничества в рамках восточного партнёрства \\
\hline EC & Европейский союз \\
\hline $\mathrm{GIZ}$ & Германское общество по международному сотрудничеству \\
\hline ИКТ & информационные и коммуникационные технологии \\
\hline Км & километр \\
\hline ММСП & микро, малые и средние предприятия \\
\hline PATRIP & Программа региональной интеграции Пакистан-Афганистан-Таджикистан \\
\hline KHP & Китайская Народная Республика \\
\hline ЦЦУР & цель устойчивого развития \\
\hline SWOT & сильные стороны, слабые стороны, возможности и угрозы \\
\hline $\mathrm{OOH}$ & Организация Объединенных Наций \\
\hline ПРОOH & Программа Развития ООН \\
\hline АВП & ассоциация водопользователей \\
\hline
\end{tabular}




\section{Исполнительное резюме}

\section{1. Исполнительное резюме}

В октябре 2017 года Программа Центральноазиатского регионального экономического сотрудничества (ЦАРЭС) утвердила новую стратегию ЦАРЭС 2030 с миссией «объединять людей, политику и проекты для совместного и устойчивого развития». ЦАРЭС 2030 группирует деятельность в пять операционных кластеров, включая новый кластер по человеческому развитию, и обязуется содействовать экономическому и социальному сотрудничеству между трансграничными сообществами.

Это исследование направлено на оценку того, каким образом ЦАРЭС, как платформа регионального сотрудничества, может способствовать более тесному экономическому и социальному сотрудничеству и контактам между людьми среди приграничных сообществ, и предложить направления и возможности для расширения инициатив по развитию трансграничных сообществ в регионе.

В то время как формальная функция границы заключается в контроле и ограничении передвижения людей и товаров, приграничные сообщества в регионе ЦАРЭС веками взаимодействовали для торговли, труда, здравоохранения и образования, развивая связи и создавая потенциал для большего регионального сотрудничества и общего экономического роста.

\section{2. Регион ЦАРЭС}

Страны ЦАРЭС занимают обширную географическую территорию, составляющую тысячи километров, имеют общие границы и глубокие исторические и культурные связи. Однако они говорят на разных языках и представляют политические, экономические и этнические различия. С геополитической точки зрения, 11 стран ЦАРЭС являются членами разных и лишь частично перекрывающихся региональных объединений и программ.

Хотя границы ЦАРЭС и имеют свои уникальные характеристики, у них есть определенные общие препятствия для улучшения передвижения людей через границы. К таким препятствиям относится неадекватная фризическая инфраструктура - проблема, которая стоит особенно остро с учетом огромных расстояний, трудного географического положения и доступа в некоторых странах; ограничительные процедуры визового и пограничного контроля; ограниченные инструменты приграничного сотрудничества, а также участие пограничных и местных административных органов; и трансграничная безопасность и нестабильность, часто из-за контроля над природными ресурсами. 
Кроме того, женщины, проживающие в приграничных районах, сталкиваются с определенными трудностями. В целом, гендерное неравенство сохраняется в приграничных сообществах, как и в других областях стран ЦАРЭС, и является еще более серьезным, учитывая периферийный статус этих территорий. Эти различия включают в себя такие области, как (i) доступ к достойной работе, экономическим возможностям, образованию и обучению, услугам здравоохранения, информационным и коммуникационным технологиям (ИКТ), инфрраструктуре и общественным услугам; и (ii) участие в процессах принятия решений.

\section{3. Текущее состояние приграничного сотрудничества сообществ в регионе ЦАРЭС}

Регион ЦАРЭС имеет множество границ, представляющих различные сообщества, с уникальным историческим наследием и социально-политической средой. Динамика взаимодействия приграничных сообществ между странами ЦАРЭС характеризуется несколькими факторами - такими как политический и социально-экономический контекст стран, с которыми они граничат, протяженность этих общих границ, правила в официальных и неформальных пунктах пересечения границ, этническое происхождение сообществ, а также характер экономической деятельности и возможностей в приграничных регионах. Учитывая это разнообразие, в данном исследовании используется подход, учитывающий особенности границ при анализе сотрудничества приграничных сообществ и динамики контактов между людьми на пяти отобранных границах в регионе ЦАРЭС: (i) Афрганистан и Пакистан; (ii) Афрганистан и Таджикистан; (iii) Азербайджан и Грузия; (iv) Китайская Народная Республика (КНР) и Монголия; и (v) границы в Ферганской долине (Кыргызская Республика, Таджикистан и Узбекистан). Эти границы были выбраны, чтобы представить географические различия в регионе ЦАРЭС, продемонстрировать различные стадии развития трансграничного сотрудничества сообществ и выделить различные секторальные механизмы и механизмы институциональной поддержки для приграничных сообществ в регионе.

(i) Афганистан и Пакистан. Эта граница простирается на 2430 километров (км), где этнические группы, такие как пуштуны, живут по обе стороны границы и поддерживают тесные контакты из-за своих традиционных культурных, языковых и экономических связей. В дополнение к связям, связанным с обеспечением средств к существованию - как формальным, так и неформальным, часто обеспечиваемым обширными торговыми сетями, - приграничные сообщества также полагаются на трансграничные поездки, чтобы ездить на работу и получать доступ к образованию и здравоохранению. Некоторые многообещающие трансграничные инициативы дают надежду на интеграцию. Например, Фонд Программы региональной интеграции Пакистан-Афрганистан-Таджикистан (PATRIP) построил медицинские учреждения в провинциях Хайбер-Пахтунхва и Белуджистан в Пакистане, которые также обслуживают афганские приграничные общины. Рынки приграничной торговли в пунктах пересечения границы Торхам и Веш - Чаман предлагают приграничным общинам экономические возможности и возможности для участия в торговле и бизнесе. Молодежные обмены через университеты и молодежные центры также являются проверенным инструментом для расширения контактов, приграничного сотрудничества и интеграции между двумя странами. 
(ii) Афрганистан и Таджикистан. Афрганистан также граничит с Таджикистаном на севере, разделяя 1206 км вдоль рек Амударья, Пяндж и Памир. Сельское хозяйство является основным источником дохода для тех, кто живет в приграничных районах по обе стороны. Это зависит от транспортного сообщения, доступа к рынкам и надежной доступности воды, что усиливает необходимость регионального сотрудничества. Региональное сотрудничество также необходимо, учитывая, что сельскохозяйственные сообщества по обе стороны границы подвержены стихийным бедствиям, таким как наводнения и оползни. Безопасность и нестабильность также остаются серьезной проблемой для приграничных сообществ с организованной преступностью и незаконной торговой деятельностью. Для борьбы с этими проблемами Программа развития Организации Объединенных Наций (ПРООН) реализовала такие инициативы, как Программа управления границами в Центральной Азии и Повышение уровня жизни в таджикско-афганских приграничных районах. Несколько инфраструктурных проектов, осуществляемых Сетью развития Ага Хана (AKDN), также улучшили доступ приграничных общин к рынкам и медицинским учреждениям и способствовали обмену знаниями и идеями между людьми из обеих стран.

(iii) Азербайджан и Грузия. Эти страны имеют 480 км общих границ. Жители приграничных населенных пунктов, проживающие на азербайджанской стороне, часто переходят через границу в Грузию, чтобы купить продукты и воспользоваться частными медицинскими услугами. Увеличились объемы туризма между этими двумя странами и приграничными регионами - такими как Кахети и Квемо Картли (Грузия), а также Гянджа, Шеки и Габала (Азербайджан), предлагая хорошие условия для совместного развития туристических объектов. Сельское хозяйство, а точнее производство винограда для виноделия, также играет доминирующую роль в этом приграничном регионе и предлагает возможности для разработки совместных инициатив для приграничных сообществ. Приграничный регион между Лагодехи (Грузия) и Балаканом (Азербайджан) является хорошим примером успешного приграничного сотрудничества, поскольку местные муниципалитеты совместно организуют культурные и спортивные мероприятия. Эфрфективные инициативы по продвижению приграничных сообществ включают те, которые реализованы в рамках Программы поддержки территориального сотрудничества Восточного партнерства. Программа была направлена на расширение прав и возможностей молодых людей, живущих в приграничных регионах, путем повышения их навыков трудоустройства посредством обучения и общения между потенциальными работодателями и бенефициарами. Она также была направлена на увеличение туристического потенциала в приграничных регионах, улучшение борьбы с сельскохозяйственными вредителями в приграничных районах и содействие интеграции детей с ограниченными возможностями, живущих в приграничных регионах, посредством совместных учебных курсов и информационных кампаний.

(iv) Китайская Народная Республика и Монголия. Монголия граничит на юге с двумя автономными районами КНР - Синьцзян-Уйгурским автономным районом и Автономным районом Внутренняя Монголия, разделяющих 4600 км границ. Жители приграничных общин на стороне Монголии часто пересекают границу с КНР в поисках медицинской помощи и возможностей работы в таких отраслях, как искусство, СМИ и спорт. Пункт пересечения границы между Эренхотом (Внутренняя Монголия) и ЗамынУудом (Монголия) имеет зону экономического сотрудничества, объект беспошлинной торговли, где жители приграничных общин могут продавать местные продукты. Рост 
туризма между этими странами может положительно повлиять на уровень жизни приграничных сообществ, стимулируя развитие смежных отраслей - таких как транспорт, общественное питание и развлечения.

(v) Ферганская долина (Кыргызская Республика, Таджикистан и Узбекистан). Кыргызская Республика делит 984 км с Таджикистаном и 1314 км с Узбекистаном. Общая граница Таджикистана с Узбекистаном составляет 1312 км. Ферганская долина пересекает эти три страны, объединяя сообщества из частей Баткенской, ДжалалАбадской и Ошской областей (регионов) Кыргызской Республики; Согдийской области в Таджикистане; а также из Андижана, Ферганы, Коканда и Намангана в Узбекистане. Трансграничное взаимодействие между членами сообществ происходит через формальную и неформальную торговлю и совместное использование воды и пастбищ. Эти взаимодействия поощряются безвизовым режимом и помогают укреплять доверие между сообществами, улучшать отношения и создавать трансграничные сети. Однако конкуренция за природные ресурсы и обеспечение безопасности границ по-прежнему вызывают периодические конфрликты между приграничными сообществами в долине. Тем не менее, имеются истории успешного сотрудничества между сообществами. Например, рынок Кара-Суу в Ошской области Кыргызской Республики способствовал мобильностиприграничныхсообществ в регионе. Жителиприграничныхобщинпродают на рынке свою продукцию, а потребительские товары, сельскохозяйственная и другая продукция поступает на рынок из Узбекистана. Проект развития сельских предприятий Ферганской долины поддерживает микро-, малые и средние предприятия (ММСП) в приграничных сельских районах Ферганской долины; направлен на укрепление связей в цепочках поставок; и облегчает более широкий доступ к рынкам через границы.

Как показывают приведенные выше примеры, приграничное сотрудничество может значительно улучшить возможности приграничных сообществ для получения средств к существованию и расширить их доступ к социальным услугам. Успешные программы сотрудничества сообществ были реализованы вдоль и за пределами границ ЦАРЭС и охватывают широкий спектр областей, начиная от расширения торговой деятельности и заканчивая туризмом, от образовательных обменов до улучшения доступа к медицинскому обслуживанию. Однако эти программы необходимо расширить и сделать более устойчивыми.

\section{4. Передовой международный опыт сотрудничества приграничных сообществ}

На основе этих выводов был проанализирован опыт международных организаций в продвижении трансграничного сотрудничества между сообществами. С глобальной и исторической точки зрения страны ЦАРЭС не уникальны в своем стремлении создать более объединенный регион и сообщество. Разнообразные регионы достигли этого единства, преодолевая проблемы, которые не отличаются от тех, с которыми сегодня сталкиваются страны ЦАРЭС - например, различные подходы к приграничному сотрудничеству и различия в языках, этнической принадлежности, религиозных традициях и экономическом развитии.

Уроки, извлеченные из опыта таких институтов, как Европейский союз (ЕС), Северный совет, Ассоциация государств Юго-Восточной Азии (АСЕАН) и Африканский союз (АС), актуальны для инициатив ЦАРЭС по региональному сотрудничеству в части развития приграничных 
сообществ. Например, европейские страны модернизировали инфраструктуру, чтобы уменьшить пограничные барьеры и улучшить трансграничное сотрудничество, и создали ассоциации (например, Ассоциацию европейских приграничных регионов) для укрепления регионального сотрудничества. Кроме того, опыт стран Северной Европы показывает, что можно развивать конструктивное региональное сотрудничество между очень разными странами. Опыт АCEAН показывает, что местные институциональные структуры могут быть усилены для эффрективного увеличения мобильности людей через границы. Наконец, опыт AC показывает, что прогрессивные и избранные институциональные партнерства могут способствовать увеличению объема, масштаба и устойчивости трансграничных инициатив.

\section{5. Анализ сильных и слабых сторон, возможностей и угроз}

Несмотря на некоторый прогресс, возможности для расширения трансграничного сотрудничества сообществ остаются огромными, особенно если удастся устранить некоторые из выявленных фризических барьеров и узких мест в области политики и регулирования. В этом отчете представлен краткий анализ сильных и слабых сторон, возможностей и угроз (SWOT) по усилению развития трансграничных сообществ ЦАРЭС.

(i) Сильные стороны. Программа ЦАРЭС - это устоявшаяся платформа регионального сотрудничества, которая активно взаимодействует с правительствами стран-участниц. Основное внимание в ней уделяется инвестициям и политическому диалогу в таких секторах, как связанность, торговля, образование, туризм, здравоохранение и сельское хозяйство, которые обладают огромным потенциалом для развития связанности между людьми. Приграничные сообщества в регионе ЦАРЭС часто имеют традиционные культурные, языковые и экономические связи, которые закладывают основу для интегрированных инициатив.

(ii) Возможности. ЦАРЭС может использовать трансграничные инфраструктурные проекты по всему региону для ускорения развития приграничных сообществ. ИКТ помогают ускорить процессы в пунктах пересечения границ и позволяют вести электронную торговлю. Использование ИКТ может быть увеличено за счет поддержки ЦАРЭС развития сообществ. ЦАРЭС может и дальше использовать официальные и неформальные торговые сети через границы для продвижения торговых инициатив. Региональная тенденция к упрощению визового режима может облегчить контакты с приграничными сообществами и позволить увеличить количество поездок и транзита. Богатое культурное наследие предлагает потенциал для трансграничного туризма, в развитии которого может помочь ЦАРЭС. Можно расширить проекты зон экономического сотрудничества в регионе, а также связанное с ними промышленное развитие в приграничных районах. Потенциальная поддержка ЦАРЭС ММСП в приграничных районах может увеличить экономические возможности. ЦАРЭС может сотрудничать с другими учреждениями, заинтересованными в поддержке трансграничного развития сообществ. Существующие и продолжающиеся исследования ЦАРЭС по нескольким секторам - таким как образование, туризм, здравоохранение или сельское хозяйство - предлагают важную модальность для предложения и адаптации рекомендаций для развития приграничных сообществ. 
(iii) Недостатки. Деятельность ЦАРЭС по развитию приграничных сообществ может быть затруднена из-за периферийного статуса приграничных регионов без какоголибо значительного политического влияния в столицах. Проблемы развития могут быть огромными из-за высокого уровня безработицы в приграничных районах. Среди других слабых мест - плохое предоставление государственных услуг в приграничных регионах - например, в сфере образования или здравоохранения; ограниченная мобильность людей из-за ограниченной инфраструктуры, визовых ограничений и условий безопасности; несовместимые правовые и административные системы в разных странах; недостаточная координация и обмен инфрормацией между ведомствами по управлению границами; ограниченность трансграничных институтов для обеспечения стратегических и эффрективных трансграничных перемещений товаров и людей; неоднородные межгосударственные отношения; патриархальные социокультурные обычаи, которые не позволяют женщинам в полной мере участвовать в экономической деятельности в приграничных районах.

(iv) Угрозы. Последствия изменения климата будут ощущаться, особенно в приграничных районах, подверженных стихийным бедствиям - таким как наводнения. Конкуренция за природные ресурсы может вызвать конфликты между приграничными сообществами. Политическая нестабильность и пандемии, такие как коронавирусное заболевание, могут вызвать блокировку границ.

\section{6. Рекомендации для ЦАРЭС}

В данном исследовании определен ряд рекомендаций для того, чтобы ЦАРЭС мог играть инициативную роль в расширении приграничного сотрудничества в приграничных регионах, исходя из уроков, извлеченных из передового международного опыта, и результатов SWOT-анализа. Планируемые инициативы ЦАРЭС должны обращать внимание на реализацию потенциала регионального сотрудничества через продвижение трансграничного сотрудничества сообществ в различных секторах и областях. Эти рекомендации могут быть реализованы путем принятия ориентированного на сообщества подхода и сгруппированы по трем категориям: (i) отраслевые рекомендации; (ii) институциональные рекомендации; и (iii) рекомендациипо гендерному равенству.

Предлагаемые рекомендации включают в себя проведение исследований для лучшего понимания специфических особенностей границ - таких как управление границами, сельскохозяйственные производственно-сбытовые цепочки, управление стихийными бедствиями и существующие трансграничные институты для развития приграничных сообществ, включая тех из них, которые занимаются гендерными проблемами. Рекомендации также заключаются в проведении региональных форумов, конференций и ярмарокдля создания сетей и обмена знаниями и опытом. Также предоставляется набор рекомендаций для поддержки разработки гендерной политики и создания эффективных региональных механизмов для продвижения приграничных сообществ - таких как региональная рабочая группа по торговым палатам и региональная ассоциация туроператоров. Также рекомендуется наращивание потенциала приграничных сообществ, пограничных учреждений и должностных лиц посредством проведения тренингов и программ.

АБР и другие партнеры по развитию ЦАРЭС могли бы предоставить техническую помощь в качестве начала для содействия диалогу и подготовки надежных проектных предложений для углубления сотрудничества с сообществами в регионе. Институт ЦАРЭС также может оказывать поддержку в проведении исследований, тренингов и распространении данных, касающихся сотрудничества приграничных сообществ. 


\section{1. Вступление}

\section{1. ЦАРЭС и Стратегия ЦАРЭС 2030}

1. Программа Центральноазиатского регионального экономического сотрудничества (ЦАРЭС) - это партнерство 11 стран $^{1}$ и партнеров по развитию, которые работают вместе для содействия развитию посредством сотрудничества, ведущего к ускоренному экономическому росту и сокращению бедности.

2. Стратегия ЦАРЭС 2030, одобренная 16-й Министерской конфреренцией в октябре 2017 года, обеспечивает долгосрочную стратегическую основу с миссией по объединению людей, политик и проектов для совместного и устойчивого развития в регионе. Одним из важных результатов этих усилий является содействие региональному сотрудничеству и интеграции, включая эффрективный диалог и более тесные контакты между людьми во всем регионе. ${ }^{2}$

3. Частью этой новой долгосрочной стратегии является движение ЦАРЭС к утверждению себя в качестве региональной платсрормы с более широким мандатом, который включает помощь своим странам-членам в достижении Глобальной повестки дня в области развития на период до 2030 года, Целей устойчивого развития (ЦУР) и Парижского соглашения, достигнутого на 21-й Конференции сторон Рамочной конвенции Организации Объединенных Наций $(\mathrm{OOH})$ об изменении климата. Региональный подход ЦАРЭС кразвитию трансграничных сообществ напрямую нацелен на четыре из 17 ЦУР:

(i) ЦУР 8: Достойная работа и экономический рост - Содействие инклюзивному и устойчивому экономическому росту, занятости и достойной работе для всех.

(ii) цУР 9: Промышленность, инновации и инфраструктура - Создание устойчивой инфраструктуры, содействие устойчивой индустриализации и стимулирование инноваций.

(iii) ЦУР 10: Сокращение неравенства - Сокращение неравенства внутри стран и между странами.

(iv) ЦУР 11: Устойчивые города и сообщества - Сделать города и населенные пункты инклюзивными, безопасными, жизнестойкими и устойчивыми.

1 Страны-члены ЦАРЭС - Афганистан, Азербайджан, Грузия, Казахстан, Кыргызская Республика, Монголия, Пакистан, Китайская Народная Республика (КНР), Таджикистан, Туркменистан и Узбекистан.

2 ЦАРЭС. 2017 г. ЦАРЭС 2030: Соединяя регион для совместного и устойчивого развития. Манила. 


\section{2. Цель, методология и структура обзорного исследования}

\section{Цель}

4. Данное исследование направлено на оценку того, каким образом ЦАРЭС, как платформа регионального сотрудничества, может способствовать более тесному экономическому и социальному сотрудничеству и контактам между людьми среди приграничных сообществ, и предложить направления и возможности для расширения инициатив по развитию трансграничных сообществ в регионе.

\section{Методология}

5. В исследовании проводится обзор всех приграничных территорий ЦАРЭС и выбираются пять ключевых границ для изучения национальных и региональных программ и планов, направленных на (i) создание благоприятной среды для преодоления маргинализации приграничных регионов и (ii) выработку коллективной перспективы трансграничного развития в регионе. В исследовании предлагаются инициативы в области развития путем выявления общих проблем трансграничных сообществ в приграничных регионах стран ЦАРЭС и подчеркиваются возможности для расширения контактов между людьми и реализации регионального потенциала общего развития.

6. Подход к исследованию основан на анализе сильных и слабых сторон, возможностей и угроз (SWOT) для определения общих возможностей и приоритетов развития для использования сильных сторон и уменьшения слабых сторон. Этот анализ поможет выработать инициативы с конкретными приоритетами с точки зрения качества, времени и ссрер деятельности.

7. В исследовании используются как количественные, так и качественные методы исследования для детализации трансграничных сообществ. К вторичным исследованиям относятся демографические опросы, научные журналы, аналитические заметки, отчеты доноров, межправительственные соглашения и региональные матрицы. Тематические области, затрагиваемые в рассматриваемой литературе, включают в себя социальное развитие (здравоохранение, образование, развитие по инициативе сообществ, экономическое развитие и укрепление гражданского общества); инфрраструктуру (трансграничная инфраструктурная деятельность, включая дороги, мосты и энергетику); экономическое развитие (взаимодействие бизнес-бизнес, трансграничные рынки, торговля и развитие предприятий); туризм; управление природными ресурсами; сельскохозяйственные и фермерские организации, включая ассоциации водопользователей (АВП); управление границами; и управление рисками бедствий. Также изучается деятельность ЦАРЭС в других областях - таких как туризм, образование, здравоохранение и развитие экономических коридоров, - чтобы обеспечить согласованность между прошлой и текущей работой и предлагаемыми в данном исследовании рекомендациями.

8. Полевые миссии проводятся в Азербайджане, Китайской Народной Республике (КНР), Грузии, Монголии и Таджикистане с целью расширения вторичных исследований. Проводятся встречи с заинтересованными сторонами, связанными с инициативами развития 
трансграничных сообществ - такими как доноры, агентства-исполнители, партнеры по развитию, правительственные чиновники и местные администрации, академические учреждения, частные предприятия и организации гражданского общества (общественные организации или ОО). В рамках миссий также посещаются приграничные инфраструктурные проекты, включая мосты, рынки, пункты пересечения границ и взаимные экономические зоны (Приложение 1).

\section{Структура и объем}

9. Исследование состоит из шести разделов. После вступления, в Разделе 2 определяется контекст исследования с описанием разнообразия стран ЦАРЭС, барьеров для сотрудничества приграничных сообществ и расширения контактов между людьми, а также роли женщин в приграничных сообществах.

10. В Разделе 3 рассматривается общее текущее состояние трансграничного сотрудничества между сообществами в регионе и выбираются пять границ, которые представляют географические различия в регионе ЦАРЭС, для детальной оценки: (i) Афрганистан и Пакистан; (ii) Афрганистан и Таджикистан; (iii) Азербайджан и Грузия; (iv) Монголия и Китайская Народная Республика; ${ }^{3}$ и (v) Ферганская долина (Кыргызская Республика, Таджикистан и Узбекистан).

11. В Разделе 4 определены уроки и передовой опыт трансграничного сотрудничества по всему миру.

12. В Разделе 5 проводится SWOT-анализ возможностей ЦАРЭС для поддержки развития трансграничных сообществ, за которым следует краткое описание того, как сильные стороны региона и программы могут способствовать установлению связей между людьми, как преобразовать возможности в инициативы для трансграничного развития сообществ, а также способы устранения слабых мест и угроз.

13. Раздел 6 завершается предложением ряда рекомендаций для ЦАРЭС по поддержке развития приграничных сообществ и расширению контактов между людьми в регионе, с указанием потенциальных партнеров и границ, которым следует уделять приоритетное внимание.

\section{3. Подход к взаимодействию между людьми, приграничными и трансграничными сообществами}

14. Хотя наиболее очевидная фрункция границы заключается в том, чтобы действовать как барьер и инструмент для контроля передвижение людей и товаров, границы также могут влиять на региональное развитие, учитывая их частую роль в приграничных сообществах. Эти сообщества фрормируются потому, что граница используется, законно или незаконно, для

3 Провинции Синьцзян-Уйгурский автономный район и Автономный район Внутренняя Монголия в КНР являются частью региона ЦАРЭС. 
(i) регулярного получения ресурсов - таких как работа, товары, торговля или образование; и (ii) поддержания связей через границу по другим экономическим или личным причинам. В этом контексте фрраза «трансграничные сообщества» используется в данном исследовании для обозначения людей, которые живут вблизи национальных границ и систематически пересекают их по указанным причинам.

15. Трансграничные сообщества могут положительно повлиять на процесс регионального развития, если они поддерживаются специальной экономической политикой и подходом, ориентированным на сообщества («люди с людьми»), который приводит к установлению общей идентичности приграничного региона, формированию социального капитала и укреплению доверия между приграничными сообществами, живущими по обе стороны границы. Проще говоря, можно думать об «отношениях между людьми» как о соседях, которые дружелюбны и добры друг к другу и имеют удобные и законные способы и места для взаимодействия и обмена ценностями, чтобы вся округа процветала и оставалась в безопасности. 


\section{2. Регион ЦАРЭС}

\section{1. Разнообразие стран ЦАРЭС}

16. Страны ЦАРЭС занимают обширную географическую территорию, составляющую тысячи километров (км), имеют общие границы и глубокие исторические и культурные связи. Тем не менее, они говорят на разных языках и имеют политические, экономические и этнические различия. С геополитической точки зрения, 11 стран ЦАРЭС являются членами разных и лишь частично перекрывающихся региональных объединений и программ. Например, Азербайджан, Грузия и Казахстан являются членами Европейского пространства высшего образования или Болонского процесса. ${ }^{4}$ Казахстан и Кыргызская Республика присоединились к Евразийскому экономическому союзу. ${ }^{5}$ Афрганистан и Пакистан являются членами Ассоциации регионального сотрудничества стран Южной Азии.

17. Регион ЦАРЭС состоит из стран с разным уровнем дохода: страны с доходом выше среднего (Азербайджан, КНР, Казахстан и Туркменистан); страны с уровнем дохода ниже среднего (Грузия, Кыргызская Республика, Монголия, Пакистан и Узбекистан); и страны с низкими доходами (Афрганистан и Таджикистан). Точно так же доля населения стран ЦАРЭС, живущего ниже национальной черты бедности, также отличается в зависимости от той или иной страны (Рисунок 1). Некоторые из них сильно зависят от природных ресурсов например, Азербайджан, Казахстан и Туркменистан, являющиеся крупными экспортерами нефти; и КНР, сильно зависящая от импорта нефти.

18. Различные уровни доходов в регионе ЦАРЭС привели к разным моделям трансграничного перемещения рабочей силы. Например, Казахстан является неттоимпортером рабочей силы - в основном, из соседних стран, в то время как афрганские приграничные общины полагаются на рынок поденного труда в пунктах транзита через границу между Пакистаном и Афрганистаном. Автономный район Внутренняя Монголия в КНР предлагает возможности трудоустройства и средств к существованию для приграничных монгольских общин.

19. Все эти аспекты способствуют определению самобытности приграничных сообществ, динамики их взаимодействия и препятствий на пути более активного передвижения людей через границы.

4 Азиатский банк развития (АБР). 2019 г. Образование и профессиональное обучение в рамках программы ЦАРЭС: Предварительное исследование. Манила.

5 Евразийский экономический союз - это международный экономический союз, который был создан в качестве зоны свободной торговли, позволяющей осуществлять свободное перемещение товаров, услуг, капитала и рабочей силы и проводящей скоординированную, согласованную и единую политику. 


\section{Рисунок 1: Доля населения стран ЦАРЭС, живущего ниже национальной} черты бедности (\%)

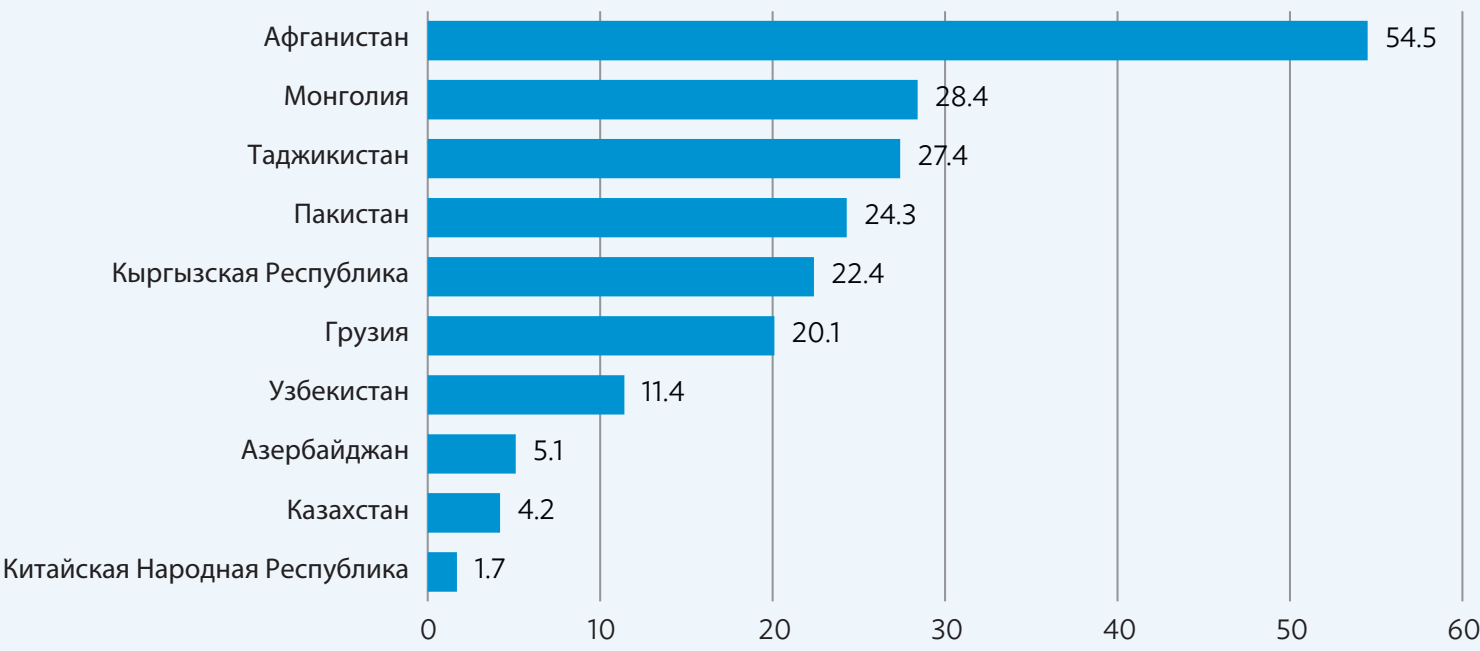

Примечания: данные за 2018 год, за исключением Пакистана (2015 г.), Афганистана (2016 г.) и Казахстана (2019 г.). Данных по Туркменистану нет. Данные по КНР отличаются от стандартного определения или относятся только к некоторым частям страны. Данные по Узбекистану относятся к предварительным данным. Источник: Азиатский банк развития. 2020 г. Базовые статистические показатели за 2020 год. Манила.

\section{2. Барьеры на пути развития трансграничных сообществ и расширения контактов между людьми}

20. Приграничные районы играют важную роль в трансграничной политической экономике и личных контактах. Динамика границ зависит от институциональной структуры, отражающей интересы национальной политики, технических и фризических барьеров и стандартов, действующих в разных странах. ${ }^{6}$ Хотя границы ЦАРЭС и обладают уникальными характеристиками, унихесть определенные общие препятствиядля улучшенияпередвижения людей через границы - например:

(i) Неадекватная материально-техническая база (физическая инфраструктура). Для стран ЦАРЭС характерны огромные расстояния и затрудненный доступ, и многие границы региона одинаково трудно пересекать из-за их нахождения в высокогорной или удаленной местности. Эти факторы способствуют высокой стоимости фризической связанности в регионе и ограничению контактов между людьми.

(ii) Ограничительные процедуры визового и пограничного контроля. Каждая страначлен ЦАРЭС использует свою собственную систему визового и пограничного режима. Получение визы подчиняется различным требованиям между странами ЦАРЭС и зависит от происхождения посетителей ЦАРЭС (Приложение 2). Многие страны ЦАРЭС достигли значительного прогресса в снижении требований к въезду для иностранных

6 Гарри Коккосис и Питер Нийкамп. 2012 г. Преодоление изоляции: информационные и транспортные сети в стратегиях развития периферийных территорий. Публикация в издании «Достижения пространственной науки» (Advances in Spatial Science). Springer Science \& Business Media. стр. 55. 
посетителей и посетителей из стран ЦАРЭС. Например, Узбекистан ввел 30-дневный безвизовый режим для граждан 45 стран (с 1 февраля 2019 года), а Пакистан планирует облегчить визовые ограничения для посетителей из 55 стран. Кроме того, система пограничного контроля почти на всех пунктах пересечения сухопутных границ часто включает длинные очереди и долгое время обработки. ${ }^{7}$

(iii) Ограниченные инструменты приграничного сотрудничества. Участие приграничных и местных административных органов в управлении трансграничными программами ограничено. В целом, в регионе ЦАРЭС нет специальных инструментов публичного права для управления трансграничным сотрудничеством. Однако некоторые местные административные органы участвуют в инициативах приграничного сотрудничества. Например, в 2011 году на китайско-казахстанской границе открылся Международный центр приграничного сотрудничества, который служит беспошлинной и безвизовой зоной для граждан обеих стран. Кроме того, развитие перевала Иркештам служит воротами для товаров между КНР и Кыргызской Республикой. Кроме того, решение Узбекистана разрешить микроторговцам пересекать границы страны привело к развитию надомного производства в таких регионах, как Ферганская долина, где переплетаются Узбекистан, Кыргызская Республика и Таджикистан.

(iv) Трансграничная безопасность и нестабильность. Приграничные районы иногда страдают от небезопасности и нестабильности, часто из-за контроля над природными ресурсами, что в конечном итоге мешает межличностным контактам между людьми и, следовательно, развитию общин. Ситуация с безопасностью границ в регионе ЦАРЭС за последние годы в некоторой степени улучшилась. Стычки между пограничниками стран-участниц ЦАРЭС редки. Более того, изменения во внешней политике Узбекистана в конце 2016 года дали положительный импульс всей региональной безопасности.

\section{3. Женщины в приграничных сообществах ЦАРЭС}

21. Женщины, живущие в приграничных районах ЦАРЭС, сталкиваются с определенными трудностями, помимо упомянутых препятствий. Будучи членами приграничных сообществ, женщины также регулярно пересекают границу, чтобы (i) получить доступ к различным ресурсам, таким как работа, предметы снабжения, торговля, образование или здравоохранение; или (ii) поддерживать личные связи с семьей и друзьями. Увеличивается частота, с которой женщины пересекают границу, поскольку уход за детьми повсеместно считается обязанностью женщин; женщины пересекают границу также в поисках услуг для своих детей.

22. В целом, гендерное неравенство сохраняется в приграничных сообществах, как и в других областях стран ЦАРЭС, в отношении участия в процессах принятия решений и доступа к достойной работе, экономическим возможностям, образованию и обучению, услугам здравоохранения, информационным и коммуникационным технологиям (ИКТ), инфраструктуре и общественным услугам. В частности, существует системный гендерный разрыв в уровне участия в рабочей силе с различиями в уровне занятости, шкалах заработной платы и качестве занятости. Существуют также гендерные предубеждения при приеме на работу и возможностях продвижения по службе, а также неспособность реализовать

7 АБР. 2019 г. Содействие региональному сотрудничеству в сфрере туризма в рамках ЦАРЭС 2030: Предварительное исследование. Манила. 
национальную политику в отношении гибких условий работы, отпуска по уходу за ребенком и равной оплаты труда. Кроме того, женское предпринимательство во многих странах подрывается такими факторами, как нехватка финансов для стартапов и расширения из-за ограниченного владения женщинами активами для получения кредитов. Участие женщин в политической жизни во всех странах ЦАРЭС значительно ниже $33 \%$, поддерживаемых Пекинской платформой действий, 8 а доля женщин на руководящих должностях остается низкой. Женщины также часто в наибольшей степени страдают от внешних потрясений таких как засуха или наводнения, - связанных с изменением климата, колебаниями цен на продукты питания и нефть и глобальными пандемиями, такими как коронавирусное заболевание (COVID-19), из-за своей непропорциональной подверженности риску и обязанностей, связанных с оказанием первичной медицинской помощи. ${ }^{9}$

23. Перифрерийный статус приграничных территорий делает это неравенство еще более острым для женщин, живущих в приграничных регионах ЦАРЭС, и создает для них дополнительные трудности. Например, неформальная и мелкомасштабная торговая деятельность является основным источником дохода для многих женщин, живущих в приграничных районах. При этом, женщины, как правило, передвигаются пешком, что делает их уязвимыми для преследований или жестокого обращения. Они также менее информированы о рыночных правилах, что увеличивает вероятность того, что они станут объектами преследований и вымогательств, что, в свою очередь, сказывается на их благополучии и сокращает их свободное время и прибыль. Женщины в странах ЦАРЭС часто несут основную ответственность за обеспечение домохозяйства водой и, таким образом, несоразмерно обременены проблемами, связанными с водоснабжением и качеством воды. Управление водными ресурсами на границах является более сложной задачей, поскольку водные ресурсы разделены международными границами, что создает дополнительное бремя для женщин. ${ }^{10}$

24. Было начато несколько инициатив по усилению роли женщин в развитии приграничных сообществ в странах ЦАРЭС. Например, проект «Приграничное сотрудничество в интересах устойчивого мира и развития» на границе между Кыргызской Республикой и Таджикистаном помог женщинам укрепить свои 11 навыки предотвращения конфрликтов, ведения переговоров и миростроительства. Имеющиеся данные свидетельствуют о том, что при участии женщин в процессах мирных переговоров вероятность заключения соглашений со сроком действия не менее 15 лет увеличивается на $35 \% .{ }^{12}$

8 Пекинская декларация и Платформа действий были одобрены на четвертой Всемирной конференции по положению женщин Организации Объединенных Наций $(\mathrm{OOH})$ в Пекине в 1995 году. В ней признаются права женщин как права человека и излагается всеобъемлющая дорожная карта для достижения равенства между женщинами и мужчинами. См. ООН-Женщины. Пекинская платформа действий.

9 Гендерная оценка ЦАРЭС формулируется для того, чтобы служить основой и обеспечивать основные входные данные для Гендерной стратегии ЦАРЭС до 2030 года. Она направлена на повышение потенциала и возможностей женщин для получения равных выгод от инвестиций ЦАРЭС и получения равного доступа к любым возможностям. Она также поддерживает национальные и региональные усилия по устранению гендерного неравенства. АБР. Проект Гендерной стратегии ЦАРЭС до 2030 г. Не опубликовано.

10 Х. С. Уоррен, М. Люнгман и Э. Янг. 2019 г. Каково это - женщинам торговать через границу? Блог Всемирного банка. 3 июня.

11 Проект был запущен в декабре 2015 года организацией «ООН-женщины», Всемирной продовольственной программой $\mathrm{OOH}$, Продовольственной и сельскохозяйственной организацией ООН, Детским фондом ООН (ЮНИСЕФ) и Программой развития ООН (ПРООН). Он финансировался Управлением ООН по поддержке миростроительства и Швейцарским управлением по развитию и сотрудничеству. См. Фрауке де Вейер. 2017 г. Обзор приграничного сотрудничества ФМС в интересах устойчивого мира и развития. Фонд PeaceNexus.

12 ООН-Женщины. 2017 г. Женщины создают мир на кыргызско-таджикской границе. Истории. 2 февраля. 


\section{3. Текущее состояние приграничного сотрудничества сообществ в регионе ЦАРЭС}

\section{1. Обзор границ ЦАРЭС}

25. Приграничные регионы ЦАРЭС не только обширны по своему географическому охвату, но и сложны по своему составу, поскольку сообщества живут между двумя обществами, культурами и экономическими системами, которые могут меняться из-за меняющейся обстановки в сфере международных отношений. Регион имеет множество границ, представляющих очень разные сообщества, с уникальным историческим наследием и текущим политическим и социально-экономическим контекстом.

26. Динамика взаимодействия приграничных сообществ между странами ЦАРЭС характеризуется несколькими факторами - такими как политический и социальноэкономический контекст стран, с которыми они граничат, протяженность этих общих границ, правила в офрициальных и неформальных пунктах пересечения границы, этническое происхождение сообщества, характер экономической деятельности и возможности в приграничных регионах.

27. Такие страны, как Азербайджан с Грузией и Монголия с КНР, граничат только с одной страной ЦАРЭС; КНР, напротив, граничит с шестью странами ЦАРЭС: Асрганистаном, Казахстаном, Монголией, Кыргызской Республикой, Пакистаном и Таджикистаном.

28. Длина этих общих границ значительно различается между странами-членами. Самой короткой является граница протяженностью около 70 км между Афганистаном и КНР, что гораздо меньше 4600-километровой границы между КНР и Монголией.

29. Вдоль этих километров границ существуют формальные (официальные) и нефрормальные (неофициальные) пограничные пункты пропуска. В то время как некоторые страны имеют всего несколько официальных пунктов пропуска (например, Казахстан с Туркменистаном), в других их более 10 (например, Узбекистан с Кыргызской Республикой и Таджикистаном). Кроме того, по всему региону часто можно найти неформальные пункты пропуска - чаще всего, на границе между Асрганистаном и Пакистаном. Анклавы в регионе - такие как Сарван, небольшая часть территории Таджикистана, со всех сторон окруженный территорией Узбекистана - добавляют сложности пограничной сети ЦАРЭС.

30. Кроме того, сообщества в границах ЦАРЭС не являются однородными в этническом отношении. В Казахстане, например, насчитывается более 100 различных этнических групп, среди которых доминируют казахи, узбеки, кыргызы, таджики, туркмены и русские. 
31. Границы объединяют разную экономическую деятельность и взаимодействие людей, что успешно происходит, например, на рынке Кара-Суу Ошской области Кыргызской Республики, граничащей с КНР. Приграничные рынки приносят товарную специализацию такую как сельское хозяйство, горнодобывающая промышленность или кустарные промыслы на Кавказе и границе между Пакистаном и Афганистаном.

\section{Таблица 1: Пограничные пункты пропуска между странами ЦАРЭС}

\begin{tabular}{|c|c|c|c|c|c|c|}
\hline $\begin{array}{c}\text { Страна } \\
1\end{array}$ & $\begin{array}{c}\text { Страна } \\
2\end{array}$ & $\begin{array}{c}\text { Км } \\
\text { границы }\end{array}$ & № & Название пункта пропуска & № & Название пункта пропуска \\
\hline A3E & ГPy & 480 & $\begin{array}{l}1 \\
2 \\
3\end{array}$ & $\begin{array}{l}\text { Красный мост } \\
\text { Садыхлы или Вахтангиси } \\
\text { Балакан или Лагодехи }\end{array}$ & $\begin{array}{l}4 \\
5\end{array}$ & $\begin{array}{l}\text { Муганло или Самтацкаро } \\
\text { Алмали или Гардабани }\end{array}$ \\
\hline \multirow{5}{*}{ АФГ } & KHP & 76 & $\begin{array}{l}1 \\
2\end{array}$ & $\begin{array}{l}\text { Перевал Вахджир } \\
\text { Перевал Тегермансу }\end{array}$ & & \\
\hline & ПАК & 2430 & $\begin{array}{l}1 \\
2 \\
3\end{array}$ & $\begin{array}{l}\text { Торхам } \\
\text { Спин Болдак (Веш - Чаман) } \\
\text { Гулам Хан }\end{array}$ & & \\
\hline & ТАД & 1206 & $\begin{array}{l}1 \\
2\end{array}$ & $\begin{array}{l}\text { Ширхан Бандар - Панджи Пойон } \\
\text { Султан Ишкашим }\end{array}$ & & \\
\hline & TKM & 744 & $\begin{array}{l}1 \\
2\end{array}$ & $\begin{array}{l}\text { Торгунди - Серхетабат } \\
\text { Акина - Ымамназар }\end{array}$ & & \\
\hline & УзБ & 137 & 1 & $\begin{array}{l}\text { Хайратан - Термез } \\
\text { Хайратан - Галаба }\end{array}$ & & \\
\hline \multirow{5}{*}{ KHP } & KA3 & 1533 & $\begin{array}{l}1 \\
2 \\
3\end{array}$ & $\begin{array}{l}\text { Хоргос - Нур Жолы } \\
\text { Майкапчагай - Жеминай } \\
\text { Бахты - Таченг }\end{array}$ & $\begin{array}{l}4 \\
5\end{array}$ & $\begin{array}{l}\text { Достык/Дружба - Алашанькоу } \\
\text { Калджат (Калжат) - Порт Дулата }\end{array}$ \\
\hline & КЫР & 858 & $\begin{array}{l}1 \\
2\end{array}$ & $\begin{array}{l}\text { Перевал Иркештам: Ош - Кашгар } \\
\text { Перевал Торугарт }\end{array}$ & & \\
\hline & MOH & 4677 & $\begin{array}{l}1 \\
2 \\
3\end{array}$ & $\begin{array}{l}\text { Эренхот - Замын-Уд } \\
\text { Булган - Такашикен } \\
\text { Бичип Зуун - Хатавч }\end{array}$ & $\begin{array}{l}4 \\
5\end{array}$ & $\begin{array}{l}\text { Шевехурен - Секхи } \\
\text { Самбер - Аркса/Аершан }\end{array}$ \\
\hline & ПАК & 438 & 1 & Перевал Хунджераб & & \\
\hline & ТАД & 477 & 1 & Перевал Кульма (перевал Карасу) & & \\
\hline \multirow{3}{*}{ КАЗ } & кЫР & 1212 & $\begin{array}{l}1 \\
2 \\
3\end{array}$ & $\begin{array}{l}\text { Кордай } \\
\text { Карасу или Ак-Тилек } \\
\text { Кеген }\end{array}$ & $\begin{array}{l}4 \\
5 \\
6\end{array}$ & $\begin{array}{l}\text { Аиша Биби - Чон-Капка } \\
\text { Сыпатай батыр } \\
\text { Чалдовар }\end{array}$ \\
\hline & TKM & 413 & $\begin{array}{l}1 \\
2\end{array}$ & $\begin{array}{l}\text { Жанаозен - Гарабогаз } \\
\text { Болашак - Серхетяка }\end{array}$ & & \\
\hline & УЗБ & 2330 & $\begin{array}{l}1 \\
2 \\
3 \\
4\end{array}$ & $\begin{array}{l}\text { Жибек-Жолы - Гишт Куприч } \\
\text { Теджен - Даут-Ата } \\
\text { Ялама - Конысбаева } \\
\text { Серке-Туркестан (Казыгурт) - } \\
\text { Ташкент }\end{array}$ & $\begin{array}{l}5 \\
6 \\
7 \\
8\end{array}$ & $\begin{array}{l}\text { Капланбек - Зангиота } \\
\text { Атамакен-Гулистан } \\
\text { Селинни - Ак Олтин } \\
\text { Сырдарья - Малик }\end{array}$ \\
\hline
\end{tabular}


Продолжение Таблицы 1

\begin{tabular}{|c|c|c|c|c|c|c|}
\hline $\begin{array}{c}\text { Страна } \\
1\end{array}$ & $\begin{array}{c}\text { Страна } \\
2\end{array}$ & $\begin{array}{c}\text { Км } \\
\text { границы }\end{array}$ & № & Название пункта пропуска & № & Название пункта пропуска \\
\hline & ТАД & 984 & $\begin{array}{l}1 \\
2 \\
3\end{array}$ & $\begin{array}{l}\text { Баткен - Исфрара } \\
\text { Кулунду - Овчи Калача } \\
\text { Маданият-Маданияй }\end{array}$ & $\begin{array}{l}4 \\
5\end{array}$ & $\begin{array}{l}\text { Карамык - Дароот Корган } \\
\text { Бор-Доба - Кызыларт }\end{array}$ \\
\hline КЫР & УЗБ & 1314 & $\begin{array}{l}1 \\
2 \\
3 \\
4 \\
5\end{array}$ & $\begin{array}{l}\text { Достык - Достлик } \\
\text { Бекабад - Ханобад } \\
\text { Маданият-Маданият } \\
\text { Кизил-Кия - Узбекистан } \\
\text { Кенсай - Учкурган }\end{array}$ & $\begin{array}{c}6 \\
7 \\
8 \\
9 \\
10\end{array}$ & $\begin{array}{l}\text { Кара-Багиш - Мингтепа } \\
\text { Баймак - Касансой } \\
\text { Сейдукум - Пушмон } \\
\text { Интимак - Кеаканер } \\
\text { Сумсар - Каракурган }\end{array}$ \\
\hline ТАД & УЗБ & 1312 & $\begin{array}{l}1 \\
2 \\
3 \\
4 \\
5 \\
6\end{array}$ & $\begin{array}{l}\text { Айвадж - Гулбахор } \\
\text { Братство - Сариасия } \\
\text { Фатехабад - Ойбек } \\
\text { Патар - Андерхан } \\
\text { Саразм-Джартепа } \\
\text { Рават }\end{array}$ & \begin{tabular}{c|}
7 \\
8 \\
9 \\
10 \\
11 \\
12
\end{tabular} & $\begin{array}{l}\text { Хаштяк - Бекабад } \\
\text { Новбунёд - Пап } \\
\text { Куштегирмон - Плотина } \\
\text { Зафрарабад - Хавасабад } \\
\text { Хаватог - Учкурган } \\
\text { Урта-Тепа - Кушкент }\end{array}$ \\
\hline TKM & УЗБ & 1793 & $\begin{array}{l}1 \\
2\end{array}$ & $\begin{array}{l}\text { Фарап - Алат } \\
\text { Телимержен-Талимарджан } \\
\text { Гасояк - Дружба }\end{array}$ & $\begin{array}{l}4 \\
5 \\
6\end{array}$ & $\begin{array}{l}\text { Дошогуз - Шават } \\
\text { Куня-Ургенч-Худжайли } \\
\text { Фарап - Ходжадавлет }\end{array}$ \\
\hline
\end{tabular}

АФГ = Афганистан, АЗЕ = Азербайджан, КНР = Китайская Народная Республика, ГРУ = Грузия, КАЗ = Казахстан, КЫР = Кыргызская Республика, км = километр, МОН = Монголия, ПАК = Пакистан, ТАД = Таджикистан, TKM = Туркменистан, УЗБ = Узбекистан.

Примечание. Страны выстроены в алфавитном порядке и каждая граница показана только один раз. Источник: Секретариат ЦАРЭС.

32. Эти различия между границами ЦАРЭС могут использоваться для разработки инициатив экономического развития в секторах, анализируемых в данном исследовании. В Таблице 1 перечислены основные официальные пункты пропуска между странами ЦАРЭС. Более подробную информацию об этих границах можно найти в Приложении 3.

\section{2. Анализ пяти отобранных границ ЦАРЭС}

33. Учитывая разнообразие приграничных регионов ЦАРЭС, в этом исследовании используется подход, учитывающий особенности границ при анализе сотрудничества приграничных сообществ и динамики контактов между людьми. Этот анализ основан на географии, характеристиках приграничных регионов, истории, социально-экономической динамике и динамике рынка труда, а также на региональных инфраструктурных проектах. Также были определены национальные и региональные программы, которые поддерживают общение людей через границы и развитие трансграничных сообществ. Учитывая сложности, которые может вызвать анализ всех границ региона ЦАРЭС, было выбрано только пять границ: (i) Афгганистан и Пакистан; (ii) Афрганистан и Таджикистан; (iii) Азербайджан и Грузия; (iv) KНР и Монголия; и (v) Ферганская долина (Кыргызская Республика, Таджикистан и Узбекистан). Эти границы были отобраны для представления географических вариаций в регионе ЦАРЭС, демонстрации того, что приграничное сотрудничество сообществ находится на разных стадиях развития, и подчеркивания различной направленности секторов и механизмов институциональной поддержки для приграничных сообществ в регионе. 


\section{(i) Граница между Афганистаном и Пакистаном}

34. Приграничный регион между Афганистаном и Пакистаном протянулся на 2430 км. Этнические группы - такие как пуштуны - живут по обе стороны границы, представляя более 4 миллионов человек, проживающих в районах, граничащих с Афрганистаном, в провинции Хайбер-Пахтунхва (Пакистан). ${ }^{13}$ Люди по обе стороны границы поддерживают тесные контакты благодаря своим традиционным культурным, языковым и экономическим связям (Вставка 1).

\section{Вставка 1: Глубокие культурные связи между афрганцами и пакистанцами}

Хайдер Хан - 35-летний мужчина, который является членом клана пуштунов Синвари, живущего в долинах Хайбер и Спингар (Белая гора) на афгано-пакистанской границе. Его семья живет на пакистанской стороне границы, а сам он работает поваром в Кабуле (Афганистан). Он сказал: «Я езжу в Пакистан каждую неделю. Каждый четверг я уезжаю из Кабула и возвращаюсь обратно в субботу». Как и у большинства людей, которые часто пересекают эту границу, у Хан нет проездных документов. Он полагается на то, что его племенные и культурные связи будут обеспечивать ему беспрепятственное перемещение.

Источник: С.К. Саифр. 2016 г. Почему граница не может разделить афранских и пакистанских пуштунов. DW. 3 июня.

35. Через эту границу проходят разветвленные торговые сети - как формальные, так и неформальные. Например, через пограничный переход Торкхам и Веш-Чаман ${ }^{14}$ оптовые товары импортируются и затем распределяются на розничные рынки по всему Афганистану. Несмотря на ограниченную инфраструктуру, приграничные рынки региона предлагают приграничным общинам экономические возможности для ведения торговли и бизнеса. Факты свидетельствуют о том, что многие афганцы пересекают границу не реже одного раза в год, и около $20 \%$ из них ведут регулярные дела с жителями Пакистана, которые не являются членами их семей. Сообщество и домашние хозяйства часто зависят от такой торговли в плане своего экономического благосостояния. ${ }^{15}$

36. Приграничные сообщества - особенно, в Афганистане - полагаются на трансграничные поездки на работу в дополнение к взаимодействиям, связанным с обеспечением средств к существованию, для доступа к образованию и здравоохранению. Из-за ограниченного количества учреждений третичного (высокоспециализированного) медицинского обслуживания в Афрганистане и, прежде всего, в периферийных приграничных районах, для получения медицинской помощи большинству жителей приграничных афрганских районов необходимо ехать в Пешавар (Пакистан).

13 Сеть свободных и честных выборов. 2019 г. Мирные, хорошо организованные выборы в недавно объединенных округах ознаменовали завершение конституционного слияния.

14 Пограничный переход Веш-Чаман объединяет город Чаман в Белуджистане (Пакистан) и Веш в Спин-Болдаке, провинция Кандагар (Афганистан).

15 А. Морел. 2020 г. Пограничные районы Асрганистана: непослушные, неуправляемые и необходимые для мира. Фоно Азии. 22 января. В исследовании изучались источники средств к существованию и торговля в Афганистане - в частности, в Спин-Болдаке в провинции Кандагар, Мухманд-Дара в провинции Нангархар, и двух округах в Торхаме и Веш-Чамане. 
37. Уже есть многообещающие трансграничные инициативы, дающие надежду на будущую интеграцию приграничных регионов. Например, Фонд Программы региональной интеграции Пакистана, Афганистана и Таджикистана (PATRIP) 16 профинансировал несколько проектов социальной и экономической инфрраструктуры в партнерстве с Wish International, ${ }^{17}$ Программой поддержки сельских районов Сархад 18 и Программой поддержки сельских районов Белуджистана ${ }^{19}$ в некоторых приграничных районах провинций Хайбер-Пахтунхва и Белуджистан в Пакистане. Например, им были построены медицинские учреждения в районах Дир и Банну ХайберПахтунхва, которые также обслуживают людей по другую сторону границы с Афрганистаном. Другой знаковый инфраструктурный проект, завершенный PATRIP - это совместный пакистанско-афганский торговый центр в Чамане, городе на пакистанской стороне границы с провинцией Кандагар (Афрганистан), который способствует обмену информацией и знаниями между торговцами и бизнесменами из приграничных сообществ.

38. Аналогичным образом, в районе Куррам в Пакистане Программа поддержки сельских районов Сархад завершила несколько проектов - таких как школы для пакистанских и афрганских детей и соединение дорог между двумя странами, обеспечение доступа к образованию и другим услугам для приграничных общин.

39. Кроме того, молодежные обмены являются проверенным инструментом трансграничного сотрудничества и интеграции. Многие афганские молодые люди учатся в пакистанских университетах и устанавливают тесные связи со своими пакистанскими сверстниками. Было создано несколько молодежных центров - например, в рамках Программы поддержки сельских районов Белуджистана в Чамане и Нушки в Пакистане, Центр исследований в области безопасности в Пакистане и Центр афганских исследований. 20 Они привлекли тысячи молодых людей из обеих стран к участию в нескольких спортивных мероприятиях, что привело к широкомасштабному установлению контактов. Молодежный диалог между Пакистаном и Афганистаном, организованный Центром афганских исследований, можно назвать передовой практикой, которая обеспечивает «платфрорму для молодежи Пакистана и Афрганистана, чтобы взаимодействовать по вопросам, вызывающим озабоченность в обеих странах, обмениваться идеями и становиться вестниками мира и сотрудничества за пределами границ». 21

16 Фонд PATRIP был основан в ноябре 2011 года немецким государственным банком развития KfW от имени Федерального министерства иностранных дел Германии. PATRIP стремится содействовать интеграции и расширять трансграничное сотрудничество и обмен между Афганистаном и соседними Пакистаном и Таджикистаном.

17 "Wish International" - национальная неправительственная организация, работающая, в основном, на территориях племен Хайбер-Пахтунхва, граничащих с Афганистаном.

18 "Sarhad Rural Support Program" - это некоммерческая неправительственная организация, работающая в ХайберПахтунхва и на территориях некоторых племен, находящихся под федеральным управлением. Расширение прав и возможностей сообществ и развитие экономики и средств к существованию являются основными подходами программы.

19 Это - некоммерческая неправительственная организация в сельских районах Белуджистана. Ранее называвшаяся пакистанско-германским проектом самопомощи, финансируемым в начале 1980-х годов немецким агентством технического сотрудничества Deutsche Gesellschaft für Internationale Zusammenarbeit (GIZ), в 1991 году она была преобразована в Программу поддержки сельских районов Белуджистана.

20 Центр афганских исследований является инициативой Центра исследований в области безопасности в Исламабаде независимого и некоммерческого аналитического и информационно-пропагандистского центра, который способствует академическим, культурным и спортивным обменам между народами Пакистана и Афганистана.

21 Центр афрганских исследований. Серия диалогов пакистанско-афрганской молодежи. 


\section{(ii) Граница между Афрганистаном и Таджикистаном}

40. Граница между Афрганистаном и Таджикистаном простирается на 1206 км от точки пересечения с Узбекистаном на западе до КНР на востоке. Реки Амударья, Пяндж и Памир почти полностью обозначают эту границу, за исключением участка Ваханского коридора в самой восточной части Афганистана.

41. Сельское хозяйство является основным источником дохода для тех, кто живет в приграничных районах по обе стороны. Это зависит от транспортного сообщения и доступа к рынкам, а также от надежной доступности воды и земли, что усиливает необходимость в региональном сотрудничестве - например, на приграничном рынке Ишкашим (Вставка 2). Эти потребности еще более остро ощущаются в приграничных районах, уязвимых перед стихийными бедствиями - такими как наводнения или оползни.

\section{Вставка 2: Приграничный рынок Ишкашим: «Ничейная земля» между Афрганистаном и Таджикистаном}

Река Пяндж определяет границу между Ишкашимом в Афганистане и одноименным городом в Таджикистане на другой стороне. Поскольку река считается «нейтральной территорией», к ней могут легко добраться как афганцы, так и таджики, по возвращении в свои страны после посещения соседней страны. В центре реки Пяндж находится приграничный рынок - базар Ишкашим. Это - полоса нейтральной земли, на которой местные жители обеих стран собираются вместе для торговли.

Источник: Atlas Obscura. Ишкашимский приграничный рынок

42. Безопасность и нестабильность границ являются серьезной проблемой для приграничных сообществ из-за организованной преступности и незаконной торговли. Для борьбы с этими проблемами Программа развития Организации Объединенных Наций (ПРООН) при фринансовой поддержке Европейского союза (EC) в 2003 году запустила Программу управления границами в Центральной Азии. Эта программа была направлена на повышение безопасности и содействие торговле в Казахстане, Кыргызской Республике, Таджикистане, Туркменистане и Узбекистане. Основываясь на уроках, извлеченных из этого проекта, ЕС также оказывает аналогичную поддержку Афганистану в наращивании потенциала агентств по управлению границами и модернизации инфраструктуры. ПРООН также реализуетаналогичную программу комплексного управления границами под названием «Управление границами в Северном Афганистане».22 Проект способствовал повышению потенциала афрганской пограничной полиции по обеспечению безопасности границ Афганистана посредством развития потенциала, улучшенной внутренней координации и расширенного трансграничного сотрудничества между странами. Обе программы являются критически важными мерами по контролю за границами и улучшению услуг инфраструктуры в пунктах пересечения границ, чтобы способствовать легальному перемещению людей и трансграничной торговле.

22 Финансируемая ЕС служба управления границами в Северном Афганистане поддерживает трансграничную безопасность и сотрудничество. Она помогает Правительству Афрганистана налаживать экономические и политические отношения между Афрганистаном и остальными странами региона путем содействия экономическому развитию и стабильности. См. ПРООН. Управление границами в Северном Афганистане II (BOMNAF II). 
43. Другой реализуемый ПРООН проект - это Улучшение условий жизни в таджикскоафганских приграничных районах. ${ }^{23}$ Географические области, охваченные этим проектом на первом этапе, включали в себя восемь районов Хатлонской области Таджикистана. В Афгганистане проект был реализован в районе Имам Сахиб в провинции Кундуз, а также в районах Дашт-э-Кала и Янги-Кала провинции Тахар для поддержки справедливого развития и роста за счет деятельности, приносящей доход.

44. Сеть Развития Ага Хана (AKDN) ${ }^{24}$ - известная международная неправительственная организация с надежной программой трансграничного развития в этом приграничном регионе. Трансграничная программа АКДН основана на комплексном подходе к развитию территорий и ориентирована на наиболее изолированные районы и уязвимые общины на севере Афрганистана и соответствующих приграничных районах. Программа 25 развивалась с момента завершения строительства первого трансграничного моста в 2006 году, который связал Шугнанский район Афрганистана с городом Хорог в Таджикистане. За 10 лет AKDN в сотрудничестве с правительствами обеих стран построила еще четыре моста в рамках своего обязательства по повышению региональной стабильности и процветания в Горном Бадахшане в Таджикистане и провинции Бадахшан в Афрганистане. Трансграничные мосты предоставили афганцам доступ к трансграничным рынкам и «важным социальным услугам, таким как неотложная медицинская помощь в таджикских больницах, и создали более эффрективные каналы доставки гуманитарной помощи в некогда удаленные районы». ${ }^{26}$ С увеличением числа ${ }^{27}$ людей, пользующихся мостами, отношения между людьми из двух стран укрепились, а сообщества получили пользу от обмена знаниями и опытом.

\section{(iii) Граница между Азербайджаном и Грузией}

45. Граница между Азербайджаном и Грузией составляет 480 км. Страны являются стратегическими партнерами, и их успешное сотрудничество распространяется на торговлю и инвестиции, энергетику, транспорт, банковское дело и фринансы, сельское хозяйство, спорт, образование и культуру. ${ }^{28}$ Развитие в приграничных регионах между этими странами значительно отличается от остального региона ЦАРЭС, поскольку приграничные районы относительно хорошо развиты из-за более высоких уровней доходов и экономической интеграции между ними.

23 Запущенная в 2014 году при финансовой поддержке правительства Японии программа «Улучшение источников средств к существованию на таджикско-афганских приграничных территориях» (LITACA) изначально представляла собой трехлетнюю инициативу по обеспечению стабильности и безопасности в целевых сообществах в Таджикистане и Афганистане в партнерстве с соответствующими профильными министерствами. Вторая фаза, LITACA II (2018-2020 гг.), также реализуемая при финансовой поддержке Японии, направлена на повышение потенциала местных органов власти, создание базовой инфраструктуры и продвижение экономической деятельности в 12 приграничных провинциях и районах между Таджикистаном и Афрганистаном.

24 Сеть развития Ага Хана.

25 К. Уилтон-Стир. 2018 г. Воссоединение афганского и таджикского Бадахшана: экономическое развитие в приграничном регионе. Фонд Ага Хана, Великобритания. 19 декабря.

26 Поскольку регион очень подвержен стихийным бедствиям, включая наводнения, оползни и землетрясения, оказывать чрезвычайную помощь в афганском Бадахшане намного проще, чем в таджикском Бадахшане - из-за небольшого расстояния.

27 Согласно данным, предоставленным таджикскими пограничными службами на приграничном рынке Дарваз, 400-500 афрганцев переходят по мосту каждую субботу, чтобы попасть на рынок.

28 Грузинская торгово-промышленная палата в Тбилиси проинформировала полевую миссию АБР о том, что грузинские компании, занимающиеся информационными технологиями, стремятся расширить свою деятельность в Баку (Азербайджан), поскольку их рынок предоставляет возможности для расширения, и что базирующиеся в Тбилиси розничные торговцы и поставщики медицинских услуг обслуживают азербайджанских клиентов. 
46. Приграничное сообщество преимущественно является сельским, за исключением Квемо Картли, Грузия, где урбанизация составляет около 40\%. В Шеки-Загатальском экономическом районе Азербайджана 27,6\% населения проживают в городах, а $72,4 \%$ в сельской местности. В Гянджа-Газахском районе Азербайджана 46,3\% населения проживают в городах, а 53,7\% - в сельской местности. ${ }^{29}$ Около 500 тысяч этнических азербайджанцев проживают в приграничных районах Грузии и Азербайджана. 30 Либерализованный взаимный визовый режим поддерживает трансграничное перемещение приграничных сообществ. Жители города Марнеули в Квемо Картли - грузинском регионе, граничащем с Азербайджаном - являются этническими азербайджанцами и часто имеют двойные паспорта. Общинам этнических азербайджанцев в Грузии сложно интегрироваться в грузинское общество из-за возрастающих языковых и коммуникативных барьеров. Это потенциально может привести к дальнейшей маргинализации азербайджанских женщин. ${ }^{31}$

47. Приграничные общины с азербайджанской стороны часто переходят на грузинскую сторону, чтобы купить различные продукты и воспользоваться частными медицинскими услугами. Приграничный регион между Лагодехи (Грузия) и Балаканом (Азербайджан) является хорошим примером успешного приграничного сотрудничества, поскольку местные муниципалитеты совместно организуют культурные и спортивные мероприятия.

48. Туризм между этими двумя странами увеличился. Приграничные регионы - такие как Кахети и Квемо Картли в Грузии, а также Гянджа, Шеки и Габала в Азербайджане, предлагают хорошие условия для совместной разработки туристических продуктов (сноска 7). В этом пограничном регионе имеется множество древних памятников культуры, некоторые из которых относятся к каменному веку, а также природными объектами -от термальных источников до горных вершин. Совместные туристические продукты были разработаны в рамках таких инициатив, как Программа территориального сотрудничества Восточного партнерства (ЕАРТС)32 (вставка 3).

\section{Вставка 3: Трансграничный туристический маршрут между Азербайджаном и Грузией}

Проект Программы территориального сотрудничества в рамках восточного партнёрства «Гражданское общество для развития и сотрудничества: повышение туристического потенциала в приграничных регионах Азербайджана и Грузии» позволил Центру общественного образования Кода в регионе Квемо Картли (Грузия) и Общественному объединению Гянджинского регионального женского центра в Гянджа-Газахском районе (Азербайджан), в числе прочего, добиться совместной разработки пяти туристических маршрутов, два из которых являются трансграничными между Азербайджаном и Грузией. Эти маршруты позволяют туристу открыть для себя немецкое наследие в этих приграничных регионах и других культурных объектах.

Источники: Общественный образовательный центр Кода; и Меготури. О нас.

29 Программа территориального сотрудничества в рамках восточного партнерства (ЕАРТC). Совместная операционная программа Азербайджан-Грузия. стр. 5.

30 И. Гасанлы. 2018 г. Страновой отчет: Границы Азербайджана. Центр национальных и международных исследований.

31 Союз азербайджанских женщин Грузии, некоммерческая неправительственная организация в Марнеули, Квемо Картли, продвигает ассоциацию азербайджанских женщин Грузии для защиты их прав и поддержки демократических реформ и гражданского общества в Грузии.

32 Deutsche Gesellschaft für Internationale Zusammenarbeit (GIZ). Программа территориального сотрудничества в рамках восточного партнерства в контексте программы местного управления: Южный Кавказ. 
49. Сельское хозяйство также играет доминирующую роль в развитии приграничных общин в таких регионах, как Шеки-Габала в Азербайджане и Кахети в Грузии. В этих регионах виноградарство, выращивание винограда и виноделие имеют исторические корни, и сопутствующие товары широко экспортируются, что также открывает возможности для разработки совместных инициатив по развитию приграничных общин.

50. Тесные связи между двумя странами были дополнительно укреплены программой ЕС по территориальному сотрудничеству Восточного партнерства (ЕАРТС), направленной на (i) расширение прав и возможностей молодых людей, живущих в приграничных регионах, путем повышения их навыков трудоустройства посредством обучения и общения между потенциальными работодателями и бенефициарами, (ii) увеличение туристического потенциала в приграничных регионах, (iii) улучшение борьбы с сельскохозяйственными вредителями в приграничных районах и (iv) содействие интеграции детей с ограниченными возможностями, проживающих в приграничных регионах, посредством совместных учебных курсов и информационных кампаний.

51. Финансируемый EC проект «Красный мост»33 также оказался преобразующим трансграничным инфраструктурным проектом, оказав поддержку правительствам Азербайджана и Грузии в обеспечении безопасности своих границ и облегчении законного проезда людей и товаров между Гянджа-Газахским районом (Азербайджан) и деревней Муганло в регионе Квемо Картли (Грузия).

\section{(iv) Граница между Китайской Народной Республикой и Монголией}

52. Монголия граничит на юге с двумя автономными районами КНР - Синьцзян-Уйгурским и Внутренней Монголией, разделяющих 4600 км границ. Западная оконечность отмечена горами Алтая в Синьцзяне, а пустыня Гоби является частью восточной оконечности границы. Во Внутренней Монголии проживает значительное число монголов - более 4 миллионов человек; это - самое большое монгольское население в мире (больше, чем в Монголии). ${ }^{34}$

53. КНР и Монголия являются стратегическими торговыми партнерами, ${ }^{35}$ на долю которых приходится более $70 \%$ двусторонней трансграничной торговли через один из основных пунктов пропуска между двумя странами: один между Эренхотом (Автономный район Внутренняя Монголия в КНР) и Замын-Уудом (Монголия). ${ }^{36}$

33 Проект «Красный мост» направлен на улучшение стандартов фритосанитарного и ветеринарного контроля в этом пункте пропуска. Для этого были проведены программы повышения квалификации персонала пункта пропуска. Кроме того, была развита материально-техническая база и предоставлено необходимое оборудование по обе стороны границы. Например, в Азербайджане была построена охраняемая таможенная зона, а в Грузии созданы контрольные объекты. См. ПРООН. Строительство пограничного пункта пропуска Красный мост между Грузией и Азербайджаном.

34 Р. Чжоу. 2019 г. Монгольское меньшинство. China Highlights. 17 января.

35 China Daily. 2014 г. Китай и Монголия переходят к всеобъемлющему стратегическому партнерству. Монголия и КНР повысили в 2014 году свои двусторонние отношения до стратегического партнерства, в котором определены конкретные приоритетные области для расширения и обеспечения экономического сотрудничества, такие как природные ресурсы, инфраструктура и усиление межгосударственных политических коммуникаций между государствами.

36 В 2019 году объем торговли между Монголией и КНР достиг 8,9 млрд долларов США, что составляет 64,4\% от общего объема внешней торговли Монголии. Xinhuanet. 2020 г. Объем торговли между Монголией и Китаем в 2019 году достие 8,9 млрд долларов США. 26 января. 
54. Зона приграничного экономического сотрудничества Эренхот-Замын-Ууд 37 находится в этом пункте пересечения границы. Она углубляет торговое сотрудничество между двумя странами и способствует развитию приграничных сообществ с помощью зоны беспошлинной торговли, где приграничные сообщества могут арендовать торговые площади для реализации местной продукции за $5 \%$ от своего ежемесячного дохода от бизнеса. Соглашение о свободной торговле между КНР и Монголией, переговоры по которому ведутся в настоящее время, будет способствовать укреплению этого двустороннего сотрудничества. Во Внутренней Монголии приграничный город Уланкаб является торговым узлом для товаров из КНР, таких как продукция легкой промышленности, фрукты и овощи, которые позже экспортируются в Монголию, Российскую Федерацию и Европу через службы «China Railway Express». Минералы и древесина из Российской Федерации и Монголии вывозятся в КНР возвращающимися поездами. 38 Эта экономическая деятельность также способствует развитию приграничных общин.

55. С точки зрения мобильности людей, граждане Монголии могут путешествовать в КНР без визы на 30 дней. Таким образом, приграничные монгольские общины могут свободно передвигаться и покупать оптом товары в КНР для своих местных рынков. Автономный район Внутренняя Монголия в КНР предлагает монголам возможности трудоустройства, в основном в таких отраслях, как СМИ, спорт и искусство. Для въезжающих в Монголию китайцев попрежнему требуется получение визы до поездки.

56. Туризм играет ключевую роль в трехстороннем сотрудничестве между КНР, Монголией и Российской Федерацией. В 2016 году эти страны создали международный туристический альянс «Великий чайный путь» в связи с растущей привлекательностью Российской Федерации и Монголии как туристических направлений для китайских путешественников. ${ }^{39}$ В рамках этого альянса был совместно разработан широкий спектр сопутствующих туристических продуктов - таких как международный беспилотный тур, специальный поезд и летний лагерь. ${ }^{40}$ В июне 2019 года в Уланкабе (Автономный район Внутренняя Монголия в КНР) прошла выставка культурного туризма Великого чайного пути, целью которой было продемонстрировать историю и культуру Великого чайного пути и уникальные местные культуры, туристические пейзажи, культурные и творческие продукты, объекты нематериального культурного наследия. и трансграничные туристические маршруты. ${ }^{41}$ Предполагается, что этот рост туризма в значительной степени повлияет на возможности получения средств к существованию для вовлеченных сообществ и ускорит интенсивное развитие других смежных отраслей - таких как транспорт, общественное питание и развлечения.

57. Местное правительство Эренхота в Автономном районе Внутренняя Монголия (КНР) также поддерживает жителей провинции Восточная Гоби в Монголии, которые обращаются за

37 В 2015 году КНР и Монголия договорились выделить 9 квадратных километров с каждой стороны границы для совместной экономической зоны, которая занимает земли в Эренхоте (Внутренняя Монголия) и Замын-Ууде (Монголия).

38 CGTN. 2018 г. Прослеживая древний Шелковый путь: Уланкаб: Новое будущее старых караван-сараев. 4 октября.

39 В 2018 году КНР посетили более 2,4 млн российских туристов, что на 3\% больше, чем в прошлом году. Число посетителей из Монголии в КНР увеличилось на 2,8\% и превысило 1,9 миллиона человек. Монголия приняла около 200000 китайских посетителей, что на 19\% больше. Бизнес в России сегодня. 2019 г. Россия расширяет туристические связи с Китаем и Монголией. 24 июня.

40 Ху Чжэ. 2019 г. Совещание Китая, России и Монголии по вопросам укрепления трехсторонних туристических связей. China Daily. 24 июня

41 China Daily. 2019 г. В Уланчабе открылась выставка культурного туризма «Чайный путь». 24 июня. 
медицинской помощью в КНР, предоставляя им 20\% скидку на лекарства и лечение. В рамках этой инициативы около 2 000-3 000 монголов из провинции Восточная Гоби ежегодно получают лечение в Эренхоте. В отсутствие таких инициатив приграничным общинам Монголии пришлось бы проехать 3000 км до столицы Улан-Батора для получения медицинской помощи.

\section{(v) Ферганская долина: Кыргызская Республика, Таджикистан и Узбекистан}

58. Ферганская долина охватывает территорию трех стран - Кыргызской Республики, Таджикистана и Узбекистана. Кыргызская Республика имеет общие границы с Таджикистаном (984 км) и Узбекистаном (1314 км), а Таджикистан имеет общую границу с Узбекистаном протяженностью 1312 км. Ферганская долина пересекает эти три страны, объединяя сообщества из части Баткенской, Джалал-Абадской и Ошской областей Кыргызской Республики; части Согдийской области в Таджикистане; а также Андижана, Ферганы, Коканда и Намангана в Узбекистане.

59. Это - сложный в этническом плане регион, состоящий, в основном, из кыргызов, таджиков и узбеков. На территории Ферганской долины проживает почти четверть населения пяти стран Центральной Азии (Казахстан, Кыргызская Республика, Таджикистан, Туркменистан и Узбекистан), привлекаемая благоприятными условиями данной территории. «При общей численности населения в 14 миллионов во всех трех странах, часть Ферганской долины, расположенная в Узбекистане, является самой большой, с населением около 9,3 миллиона человек, что составляет $28 \%$ всего населения Узбекистана» 42 - крупнейшей заинтересованной стороны в долине с точки зрения площади территории и численности населения.

60. Последние события и расширение сотрудничества между этими странами улучшили взаимосвязь между приграничными регионами и взаимодействие людей. Например, в 2018 году Узбекистан и Таджикистан подписали соглашение о стратегическом партнерстве и открыли более 10 новых пограничных пунктов пропуска. Точно так же Узбекистан и Кыргызская Республика мирно ведут переговоры о демаркации границы, и ими достигнут прогресс в строительстве железнодорожной линии, которая может еще больше улучшить связанность между ними и КНР. Передвижение людей между этими тремя странами разрешено без визы.

61. Трансграничное взаимодействие между членами приграничного сообщества происходит посредством формальной и неформальной торговли (Вставка 4). Рынок КараСуу в Ошской области является одним из крупнейших рынков в Кыргызской Республике и Ферганской долине, и представляет собой успешную практику продвижения мобильности приграничных сообществ. ${ }^{43}$ После запуска крупного пограничного пункта пропуска Достук между Кыргызской Республикой и Узбекистаном количество выходящих на рынок клиентов из Узбекистана увеличилось. Сам рынок пополнился сельскохозяйственной продукцией с приграничных территорий, хотя большая часть товаров поступает из КНР.

42 Всемирный банк. 2018 г. Информационный документ о проекте/Комплексный перечень данных по гарантиям: Процветающие села Узбекистана. 10 сентября. стр. 9.

43 Умотбай уулу Дастан. 2018 г. День на крупнейшем рынке Ферганской долины. Центральноазиатское бюро аналитической отчетности. 17 октября. 


\section{Вставка 4: Неформальная экономика на кыргызско-таджикской и кыргызско-узбекской границе}

Эльмира живет в Баткене - селе на границе между Кыргызской Республикой и Таджикистаном. Она регулярно пересекает границу с таджикской стороной, чтобы купить дешевые товары для дома, а затем продает их на рынке на кыргызской стороне по более высокой цене. Контрабанда небольших партий товаров и продуктов - обычная практика для многих жителей приграничных регионов, таких как Эльмира. Они избегают таможенного режима, установленного после того, как в 2015 году обе страны стали членами Евразийского экономического союза.

Район Достук на границе между Ошской областью Кыргызской Республики и Узбекистаном, также является местом, где можно наблюдать мелкую контрабанду. Соль часто ввозится контрабандой из Узбекистана в Кыргызскую Республику мужчинами на велосипедах, а женщины ввозят в страну алюминий.

Источник: Д. Маматова. 2018 г. Центральноазиатская долина, где границы растворяются в массовом сотрудничестве. OpenDemocracy. 7 декабря.

62. Проект развития сельских предприятий Ферганской долины ${ }^{44}$ поддерживает микро, малые и средние предприятия (ММСП) в приграничных сельских районах Ферганской долины. Он направлен на укрепление связей в цепочках поставок и облегчение доступа к рынкам в приграничных сельских районах - таких как Андижан, Фергана и Наманган в Узбекистане.

63. Общее использование воды и пастбищ также способствует укреплению доверия между сообществами, улучшению отношений и созданию трансграничных сетей. Однако нехватка воды и неэффективное управление водными ресурсами по-прежнему вызывают периодические конфрликты между приграничными сообществами в долине. Ирригационные каналы в Ферганской долине образуют исключительно комплексную сеть. Чрезмерное использование водных ресурсов сообществами, расположенными выше по течению, часто ограничивает потребление воды теми, кто находится ниже по течению. В целях снижения риска были созданы ассоциации водопользователей (АВП) для управления водными ресурсами и эксплуатации ирригационно-дренажной инфраструктуры на бывших территориях колхозов. Хотя международные доноры и сыграли активную роль в первоначальном создании АВП, для их превращения в эффективные организации все еще требуется дополнительная поддержка. 45 Ожидаемый рост населения на 35-40\% к 2050 году создает огромную нагрузку на и без того скудные ресурсы в регионе и усиливает конкуренцию за рабочие места. Обеспечение безопасности границ также приводит к эпизодическим конфрликтам между приграничными сообществами в долине. ${ }^{46}$ Однако эта проблема преодолевается посредством повседневного сотрудничества - как в Ферганской долине (Вставка 5).

44 Всемирный банк. 2019 г. Проект развития сельских предприятий Ферганской долины.

45 И. Абдуллаев, Д. Казбеков, Г. Мантритилаке и К. Джумабоев. 2009 г. Группы водопользователей в Центральной Азии: новая форма коллективных действий в управлении оросительной водой. Управление водными ресурсами. 24 (5). стр. 1029-1043.

46 Университет Центральной Азии. 2019 г. Кыргызская Республика. Семинар «Текущая динамика приграничных территорий в Ферганской долине». 14 февраля. 
Вставка 5: Совместное использование воды и пастбищ на кыргызскотаджикской границе

Ассоциации водопользователей (АВП) управляют различными гидрографическими зонами в Ферганской долине. Мырза-Патча - село в административном районе Исфрана Баткенской области Кыргызской Республики. Однако это село не входит в соответствующую гидрографическую зону АВП. Река Иссрана протекает вдоль кыргызско-таджикской границы и является основным источником воды для людей, живущих по обе стороны границы. В случае схода селей соседние общины организуют «ашар» (коллективный труд) для расчистки русла реки.

Жители, живущие вдоль этой границы, также делят пастбища. Между кыргызскими и таджикскими жителями, главами пастбищных комитетов и главами сел заключены неофициальные договоренности о том, чтобы сельские жители Таджикистана пасли свой скот на пастбищах Мырза-Патча.

Источник: Д. Маматова. 2018 г. Центральноазиатская долина, где границы растворяются в массовом сотрудничестве. OpenDemocracy. 7 декабря.

\section{3 Ключевые выводы из анализа границ ЦАРЭС}

64. Трансграничные сообщества, проживающие в приграничных районах, описываемых выше, сильно различаются из-за разнообразия региона ЦАРЭС. На них влияет их история и нынешнее состояние отношений между странами. Тем не менее, можно выделить следующие общие факторы для разработки и реализации потенциальных инициатив по содействию связанности между людьми и развитию приграничных сообществ:

(i) Приграничное сотрудничество может значительно улучшить возможности приграничных сообществ для получения средств к существованию и расширить их доступ к социальным услугам.

(ii) Институциональные усилия по созданию благоприятной среды для трансграничного сотрудничества и контактов между людьми часто ограничены. Успешные инициативы вовлекают полностью вовлеченные местные административные органы, которые поддерживаются национальной политикой и учреждениями.

(iii) Там, где правила мобильности людей - такие как визовый режим или пункты пропуска являются дружественными, трансграничные инициативы более эффрективны.

(iv) Успешные программы сотрудничества сообществ были реализованы вдоль и через границы ЦАРЭС и охватывают широкий спектр секторов - от расширения торговой деятельности до туризма, и от образовательных обменов до улучшения доступа к необходимым удобствам - таким как здравоохранение.

(v) Существующие инициативы необходимо расширять и делать более устойчивыми.

(vi) Уязвимые группы в приграничных сообществах - такие как молодежь, женщины и девочки, дети и пожилые люди - сталкиваются с особыми проблемами. Следовательно, необходимо разрабатывать соответствующие инициативы для целевых бенефициаров.

(vii) Изменение климата подвергает население приграничных регионов непропорциональному воздействию из-за их культурного и институционального разнообразия и неравномерного экономического развития.

(viii) Несколько программ и организаций реализуют инициативы по продвижению контактов между людьми и развитию приграничных сообществ с местным опытом. ЦАРЭС может также стремиться к установлению партнерских отношений с AKDN, EC, PATRIP и ПРОOН, среди прочих. 


\section{4. Передовой международный опыт сотрудничества приграничных сообществ}

65. Опираясь на эти выводы, команда проанализировала опыт международных организаций по продвижению трансграничного сотрудничества приграничных сообществ. Опыт показывает, что успешное трансграничное сотрудничество случается там, где региональные, национальные и местные участники, включая правительства, местные ассоциации и организации гражданского общества (ОО), эффекктивно вовлечены и берут на себя ответственность. Укрепление региональных и местных органов является наиболее подходящим механизмом на административном уровне для эффективного приграничного сотрудничества, которое повысит их авторитет и гибкость для оказания необходимой поддержки приграничным сообществам, чтобы гарантировать, что структуры по обе стороны границы обладают сбалансированной компетенцией. 47

66. С глобальной и исторической точки зрения страны ЦАРЭС не уникальны в своем стремлении создать более объединенный регион и сообщество. Разнообразные регионы достигли успеха в решении проблем, не отличающихся от тех, с которыми сегодня сталкиваются страны ЦАРЭС, как видно в Европейском союзе (ЕС), регионе Северной Европы, Ассоциации государств Юго-Восточной Азии (АСЕАН) и Африканском союзе (AC). 48 Эти примеры предлагают полезные аналогии и примеры трансграничного сотрудничества на фоне разнообразных экономических и культурных условий их членов.

\section{1. Европейский Союз}

67. В 1950-х годах, после Второй мировой войны, представители нескольких европейских приграничных территорий обсуждали способы ослабления ограничений, обусловленных пограничными барьерами, и изучали возможности трансграничного сотрудничества для повышения уровня жизни приграничных сообществ, обеспечения мирных условий жизни и ослабления пограничных ограничений и других фракторов. Строительство мостов и туннелей также способствовало преодолению естественных границ. С целью улучшения приграничного сотрудничества европейские страны создали местные и региональные ассоциации по обе стороны границы. Например, Ассоциация европейских приграничных регионов была основана в 1971 году, создавая связи с другими европейскими институтами - такими как Совет Европы, Европейский парламент, Европейская комиссия и правительства стран. 49

47 М. Слюсарчук. 2013 г. Модели партнерства и сотрудничества в приграничных регионах. AUDCE. 9 (4). стр. 267-280.

48 АС - континентальный орган, состоящий из 55 государств-членов, входящих в состав стран Африканского континента. Он был официально запущен в 2002 году как преемник Организации африканского единства (1963-1999 гг.). См. Африканский союз.

49 Н. Какубава и Т. Чинчараули. 2010 г. Трансграничное сотрудничество: Практическое руководство. Ассоциация молодых экономистов Грузии. 
68. Сеть приграничных и трансграничных регионов в Европе была движущей силой ЕС. Чтобы устранить проблемы в приграничных регионах и добиться устойчивой трансграничной интеграции, В 1980-х годах Совет Европы разработал конкретные соглашения, договоры, юридические фрормы и модели для гармонизации многих областей права. 50 Они были поддержаны национальными правительствами и позволили разработать совместные трансграничные программы. Например, для деятельности по экономическому сотрудничеству используются определенные инструменты европейского права, такие как Европейская группа по экономическим интересам или Группа по общественным интересам и компания смешанной экономики.

69. Поскольку внутренние границы ЕС были демонтированы, необходимо было защитить общие внешние границы, чтобы обеспечить прогрессивное развитие региона. Для фринансирования трансграничного сотрудничества Европейский Союз использовал различные источники фринансирования, такие как Европейский фронд регионального развития. После расширения ЕС в 2004 году и создания Шенгенской зоны ${ }^{51}$ в 2007 году был введен новый визовый режим, который упорядочил поток товаров и людей через внешние границы ЕС. До тех пор основным источником дохода и развития приграничных регионов была неофициальная мелкомасштабная торговая деятельность. Присоединение к ЕС потребовало гармонизации пограничного контроля и принятия общего визового режима и таможенных правил, что поставило под угрозу хрупкую экосистему приграничных сообществ, живущих незаявленной торговой практикой.

70. Урок, который Программа ЦАРЭС может извлечь из развития внешней границы ЕС, заключается в том, что создание ассоциаций на местном и региональном уровне по обе стороны границы может улучшить приграничное сотрудничество. По образцу Шенгенского визового соглашения ЕС предлагается виза Шелкового пути, которая «позволит посещать все страны, расположенные вдоль Шелкового пути, по единой туристической визе».52 Эта инициатива также будет иметь последствия для управления границами стран-членов ЦАРЭС, которые граничат на суше со странами, получившими визы Шелкового пути.

\section{2. Североевропейский регион}

71. Североевропейский регион, состоящий из Дании, Финляндии, Исландии, Норвегии и Швеции, разделяют тесные культурные, религиозные и исторические отношения, аналогичные отношениям между странами-членами ЦАРЭС. Скандинавские языки, как и тюркские языки в некоторых странах ЦАРЭС, тесно связаны. Финский, как и таджикский, имеет иное происхождение. Кроме того, североевропейские страны также являются членами различных организаций сотрудничества.

50 Э. Медейрос. 2018 г. «Европейское территориальное сотрудничество: теоретические и эмпирические подходы к процессу и последствиям приграничного и транснационального сотрудничества в Европе». Издательство «Springer International Publishing».

51 «Шенгенская зона означает зону, в которой 26 европейских стран отменили свои внутренние границы для свободного и неограниченного передвижения людей в соответствии с общими правилами контроля внешних границ и борьбы с преступностью». SchengenVisalnfo.com. Шенгенская зона - самая большая в мире безвизовая зона.

52 Сноска 7, стр. 21. 
72. Скандинавская модель демонстрирует, что различные подходы к сотрудничеству не обязательно должны препятствовать региональному сотрудничеству и интеграции. Она также показывает, что можно разработать эффективные механизмы регионального сотрудничества, и что различные подходы могут дополнять друг друга. На сегодняшний день сотрудничество северных стран позволяет Норвегии быть в курсе вопросов ЕС, а Швеции и Финляндии - в курсе вопросов Организации Североатлантического договора. 53

\section{3. Ассоциация государств Юго-Восточной Азии}

73. Как и страны ЦАРЭС, в государствах-членах ACEAH $^{54}$ жители разговаривают на разных языках, состоят из разных этнических групп, исповедуют разные религии и демонстрируют неравномерное экономическое развитие. АСЕАН была образована в 1967 году и с тех пор зарекомендовала себя как эффективное объединение, сосредоточенное на укреплении своих институциональных структур. ЦАРЭС может последовать этому примеру для поддержки трансграничных сообществ на местном уровне путем усиления соответствующих местных органов. Работа местных органов, конечно же, наиболее эффективна, когда поддерживается соответствующими приоритетами на национальном и международном уровнях.

\section{4. Афрриканский Союз}

74. В Африке существует несколько региональных союзов, как и в регионе ЦАРЭС. 55 Эти союзы объединяют людей из одной географической зоны для участия в торговой и коммерческой деятельности. За прошедшие годы они создали механизмы для поддержки интеграции в различных измерениях - экономическом, содействии торговле и транспорте - способствуя связям между людьми через границы и развитию приграничных сообществ. С этой целью были приняты правовые инструменты для институционализации некоторых функций этих региональных союзов.

75. Хотя успех некоторых из этих союзов и обусловлен их независимостью от формальных институтов, прогрессивные и избранные институциональные партнерства также увеличивают их масштабы, охват и устойчивость. Таким образом, АС действует как административный инструмент для надзора и направляет эти общественные органы в консолидации их ролей и операций. 56

53 С. Э. Корнелл и С. Ф, Старр. 2018 г. Региональное сотрудничество в Центральной Азии: актуальность моделей мира. Аналитик по Центральной Азии и Кавказу. 4 декабря.

54 В АСЕАН входят 10 членов: Бруней-Даруссалам, Камбоджа, Индонезия, Лаосская Народно-Демократическая Республика, Малайзия, Мьянма, Филиппины, Сингапур, Таиланд и Вьетнам.

55 К этим союзам относятся Западноафриканский экономический и валютный союз в рамках Экономического сообщества западноафриканских государств и Экономический и валютный союз Центральной Африки в регионе Экономического сообщества центральноафриканских государств. В пределах географической зоны Общего рынка для востока и юга Африки, Таможенного союза юга Афррики с его ассоциированным валютным союзом (Единое валютное пространство), Сообщества развития юга Африки и Сообщества Восточной Африки. Некоторые страны в этом регионе также объединены со странами Африканского Рога в Межправительственном органе по развитию. А. Мэтьюз. 2003 г. Региональная интеграция в Африке. В публикации «Региональная интеграция и продовольственная безопасность 8 развивающихся странах». Продовольственная и сельскохозяйственная организация Объединенных Наций. Рим.

56 И. Чириса, О. С. Дирваи и А. Мумба. 2014 г. Обзор эволюции и траектории Африканского союза как инструмента региональной интеграции. SpringerPlus. 2014 г. (3). стр. 101-114. 


\section{5. Анализ сильных и слабых сторон, возможностей и угроз}

76. 76. Несмотря на достигнутый прогресс, возможности для расширения межобщинного сотрудничества в приграничных районах остаются очень большими, особенно если удастся устранить некоторые из выявленных фризических барьеров и узких мест в области политики и регулирования. Чтобы подготовить почву для выработки рекомендаций, команда обобщила краткий анализ сильных и слабых сторон, возможностей и угроз (SWOT) ЦАРЭС для усиления развития трансграничных сообществ (Таблица 2).

\section{Таблица 2: Анализ сильных и слабых сторон, возможностей и угроз}

\begin{tabular}{|c|c|}
\hline Сильные стороны & Слабые стороны \\
\hline $\begin{array}{l}\text { - Программа ЦАРЭС - это хорошо зарекомендовавшая } \\
\text { себя платформа регионального сотрудничества } \\
\text { с активным взаимодействием с национальными } \\
\text { правительствами. } \\
\text { • ЦАРЭС } 2030 \text { предусматривает сосредоточение } \\
\text { внимания на инвестициях и политическом диалоге по } \\
\text { пяти операционным кластерам, включая некоторые } \\
\text { секторы с большим потенциалом для продвижения } \\
\text { контактов между людьми и развития приграничных } \\
\text { сообществ - такие как связанность, торговля, } \\
\text { образование, туризм, здравоохранение и сельское } \\
\text { хозяйство. } \\
\text { Несмотря на свои различия, приграничные сообщества } \\
\text { в регионе ЦАРЭС часто имеют традиционные } \\
\text { культурные, языковые и экономические связи, которые } \\
\text { закладывают основу для интегрированных инициатив. }\end{array}$ & 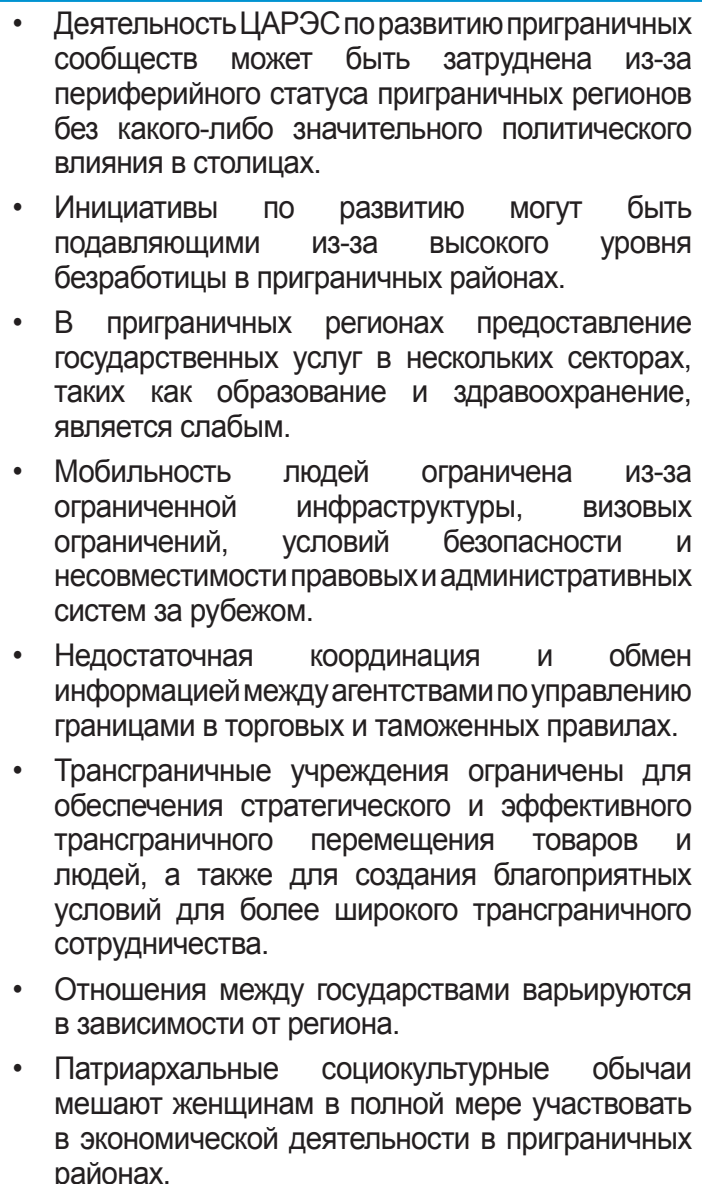 \\
\hline
\end{tabular}


Продолжение Таблицы 2

Возможности

Угрозы

- Существующиетрансграничные инфраструктурные сети и проекты могут использоваться ЦАРЭС для ускорения развития приграничных сообществ.

- Информационные и коммуникационные технологии ускоряют процессы в пунктах пересечения границы и позволяют вести электронную торговлю, и их можно было бы увеличить при поддержке ЦАРЭС для развития приграничных сообществ.

- Формальные и неформальные торговые сети через границы могли бы в дальнейшем использоваться ЦАРЭС для продвижения торговых инициатив.

- Региональная тенденция к упрощению визового режима может облегчить контакты с приграничными сообществами и позволить увеличить количество поездок и транзита между странами ЦАРЭС.

- Богатое культурное наследие региона предлагает потенциал для трансграничного туризма, развитию которого может помочь ЦАРЭС.

- Примеры проектов зон экономического сотрудничества в регионе могут быть расширены для стимулирования соответствующего промышленного развития в приграничных районах.

- Потенциальная поддержкаЦАРЭС местным микро-, малым и средним предприятиям в приграничных районах может увеличить экономические возможности.

- ЦАРЭС может сотрудничать с другими организациями, заинтересованными в поддержке трансграничного развития сообществ.

- Текущие исследования ЦАРЭС по нескольким секторам, таким как образование, туризм, здравоохранение и сельское хозяйство, предлагают важную модальность для предложения и адаптации рекомендаций для развития приграничных сообществ.

ЦАРЭС = Центральноазиатское региональное экономическое сотрудничество, COVID-19 = коронавирусная болезнь. Источник: Секретариат ЦАРЭС.

77. Следующие Разделы 5.1 и 5.2 усиливают контекст и обеспечивают стратегическую основу для поддержки рекомендаций, предлагаемых в Разделе 6.

\section{1. Использование сильных сторон и возможностей}

78. Учитывая сильные стороны ЦАРЭС как платформы регионального сотрудничества - приграничные сообщества разделяют связи и существующие благоприятные внешние факторы, такие как благоприятная внешняя политика и тенденции в регионе, среди других возможностей, - некоторые стратегии и инициативы могут быть реализованы для продвижения контактов между людьми и развития трансграничных сообществ в регионе. 


\section{(i) Использовать позитивные региональные тенденции}

79. Рефрормы в развитии Узбекистана с 2016 года положительно повлияли на перспективы регионального сотрудничества в остальных странах ЦАРЭС. Новая стратегия действий Узбекистана на 2017-2021 годы, предусматривающая внешнюю политику укрепления связей с соседними странами, в будущем обеспечит общее процветание и развитие всего региона. Кроме того, Евразийский экономический союз гарантирует свободное передвижение товаров, капитала, услуг и людей, и разрабатывает общую политику в различных секторах - таких как экономика, транспорт, промышленность и сельское хозяйство, энергетика, внешняя торговля и инвестиции, таможня и техническое регулирование. ${ }^{57}$

80. Кроме того, с 2017 года такие страны, как Казахстан, Кыргызская Республика, Узбекистан и Таджикистан, либерализовали свою въездную политику. Казахстан и Узбекистан предложили оформить визу шенгенского типа. Азербайджан и Грузия либерализовали визовый режим на основе взаимности. Граждане Монголии могут путешествовать в КНР без визы на 30 дней. Подобная политика поддерживает развитие приграничных сообществ.

81. ЦЦАРЭС следует использовать этот импульс для продвижения мобильности людей в регионе посредством инициатив, которые создают устойчивую и стабильную региональную инфраструктуру, укрепляют торговые связи и создают рабочие места и большие экономические возможности для всех стран-членов.

\section{(ii) Принять подход, основанный на инициативе сообществ}

82. Учитывая важность расширения прав и возможностей сообществ на приграничных территориях в регионе ЦАРЭС, подход к развитию, основанный на инициативе сообществ, может быть наиболее важным компонентом трансграничной программы по улучшению условий жизни и продвижению контактов между людьми. Благодаря подходу к развитию, основанному на инициативе сообществ, как мужчины, так и женщины, проживающие по обе стороны границы, могут находить решение общих проблем.

83. Наращивание потенциала местных организаций, включая женские организации, фермерские организации, ассоциации водопользователей (АВП) и комитеты пользователей пастбищ, могло бы служить эффрективной платформой для содействия местному развитию и трансграничному сотрудничеству. Региональным и национальным правительствам необходимо будет обеспечить правовую основу, позволяющую низовым учреждениям дополнять деятельность местных органов власти по развитию для планирования, реализации и управления небольшими инфраструктурными проектами, а также для улучшения предоставления других услуг государственного сектора.

\section{(iii) Опираться на рекомендации других исследований ЦАРЭС}

84. Программа ЦАРЭС сосредоточена на инвестициях и политическом диалоге по пяти операционным кластерам: (i) экономическая и фринансовая стабильность; (ii) торговля, туризм и экономические коридоры; (iii) инфраструктура и экономическая связанность; (iv) сельское хозяйство и вода; и (v) человеческое развитие. Кроме того, гендерное равенство, интеграция

57 Джим Чаппелоу. 2020 г. Евразийский экономический союз (ЕАЭС). Инвестопедия. 18 сентября. 
ИКТ и смягчение последствий изменения климата являются сквозными темами в этих пяти кластерах. Некоторые из этих секторов - такие как связанность, торговля, туризм, сельское хозяйство, образование и здравоохранение - имеют большой потенциал для установления контактов между людьми и развития приграничных сообществ. Деятельность, проводимая ЦАРЭС в этих секторах, и инициативы, предлагаемые в других обзорных исследованиях, могут быть расширены и масштабированы для достижения этой цели.

85. Туризм: развитие общинного туризма. Как указано в предварительном обзорном исследовании по продвижению регионального сотрудничества в области туризма в рамках ЦАРЭС 2030, туризм может играть важную роль в стимулировании экономического роста и продвижении внутрирегионального передвижения людей для отдыха и бизнеса в приграничных сообществах. Туризм на базе сообществ (общинный туризм) следует поощрять посредством разработки продуктов, туристической информации, развития людских ресурсов и инфраструктуры, а также укрепления региональных и субрегиональных туристических ассоциаций и проведения туристических конференций, спортивных и культурных фрестивалей. Формирование структур совместного управления на приграничных туристических объектах способствует трансграничному туризму и развитию приграничных сообществ в таких областях, как Кура, Ганых и трансграничная река Габирри на границе Грузии и Азербайджана.

86. Образование: повышение мобильности учащихся и рабочих. Рекомендации в предварительном исследовании ЦАРЭС по образованию и развитию навыков включали в себя гармонизацию стандартов и усиление взаимного признания квалификаций. На основе этих рекомендаций могут быть разработаны конкретные инициативы по продвижению мобильности учащихся и рабочих в приграничных сообществах ЦАРЭС (сноска 4). Эти инициативы могут включать в себя проведение мероприятий и виртуальных кампаний для повышения осведомленности о программах мобильности среди учебных заведений в приграничных странах, а также оказание технической и финансовой поддержки этим учреждениям для участия в этих программах.

87. Сеть университетов в приграничных регионах 58 или субрегионах может быть сформирована для более тесной координации исследований и обмена студентами. Мероприятия могут включать в себя выдачу стипендий для обучения в аспирантуре и аспирантуре с английским языком обучения, а также научные конференции и семинары по общим вопросам - таким как государственная политика, местное экономическое развитие, энергетика, вода, туризм и развитие горных территорий.

88. Такие учреждения, как Университет Центральной Азии или Назарбаев Университет в Нур-Султане (Казахстан), могут сыграть ведущую роль в привлечении студентов из региона ЦАРЭС; обеспечение непрерывного образования в различных профессиональных областях, включая подходы к развитию под руководством сообщества; и предложение исследовательских возможностей молодым специалистам из региона ЦАРЭС.

58 Хорог (Таджикистан), Ош (Кыргызская Республика), Ташкент (Узбекистан), Алматы (Казахстан), Файзабад (Афганистан), Кашгар (Синьцзян-Уйгурский автономный район, КНР), Пешавар (Пакистан), Туркменабад (Туркменистан) и Бухара (Узбекистан). 
89. Улучшение информации о рынке труда и перемещении рабочей силы. Как подчеркивается в предварительном обзорном исследовании ЦАРЭС по образованию и профессиональному обучению, некоторые страны ЦАРЭС - такие как Кыргызская Республика, Пакистан, Таджикистан и Узбекистан - «являются крупными экспортерами рабочей силы и сильно зависят от денежных переводов трудовых мигрантов как источников иностранной валюты и трудоустройства».59 «Одна из проблем, с которыми сталкиваются страны ЦАРЭС - это несоответствие между спросом и предложением навыков, и это часто происходит изза ограниченной доступности систематической информации о потребностях рынка труда» (сноска 59). В предварительном обзорном исследовании ЦАРЭС по образованию рекомендуется создать региональную информационную систему о рынке труда для содействия планированию политики в отношении рынка труда и технического и профессионального образования - как в отправляющих, так и в принимающих странах. Эта инициатива будет особенно полезна для приграничных стран, которые страдают от высокого уровня безработицы, поскольку некоторые граждане часто пересекают границу в поисках работы.

90. Здоровье. Основная цель трансграничного сотрудничества в области здравоохранения - обеспечить устойчивое улучшение состояния здоровья населения сообществ путем объединения ограниченных ресурсов и обеспечения доступа. Необходимо тесно сотрудничать с сообществами и поощрять их брать на себя ответственность за собственное здоровье. 60 Опираясь на продолжающуюся работу по составлению обзорного исследования ЦАРЭС по региональному здравоохранению, команда экспертов предложила следующие два ориентира.

91. Разработка плана трансграничного сотрудничества в области здравоохранения. Планы между соседними странами могут предусматривать открытие региональных медицинских учреждений, связанных с районными медицинскими учреждениями через границу посредством систем электронного здравоохранения. Услуги первичной медикосанитарной помощи можно улучшить спомощью модели семейной медицины. Доступ куслугам здравоохранения можно улучшить с помощью схем фринансирования здравоохранения на уровне сообществ.

92. Укрепление вторичных и третичных медицинских услуг и их открытие для трансграничного населения также можно рассматривать в качестве поддержки деятельности по человеческому развитию - такой как создание потенциала для государственных медицинских специалистов и содействие установлению связей.

\section{(iv) Развивать цепочки добавленной стоимости в сельском хозяйстве и животноводстве}

93. Сельское хозяйство является основным источником средств к существованию для людей, живущих вдоль границ ЦАРЭС. Развитие цепочек добавленной стоимости в сельском хозяйстве и животноводстве должно поддерживаться в рамках трансграничных программ, которые могут включать в себя (i) наращивание потенциала, (ii) мероприятия по обмену знаниями и (iii) продвижение региональных организаций.

59 Сноска 4, стр. 33.

60 Посредством занятий по информированию о здоровье и повышения осведомленности людей можно побудить взять на себя ответственность за свое здоровье. 
94. В части повышения квалификации (наращивание потенциала), фермеров можно обучить растениеводству и животноводству, адаптации к изменению климата и смягчению его последствий, защите растений, борьбе с болезнями и технологиям послеуборочной обработки. Также может быть оказана поддержка переработчикам в таких областях, как фритосанитарные меры и меры в отношении животных, чтобы соответствовать международным стандартам качества. Это повышение квалификации (наращивание потенциала) может быть распространено на АВП, ассоциации производителей и маркетологов, предоставляющих услуги приграничным общинам.

95. Обмен знаниями, региональные инвестиционные конференции, торговые ярмарки и форумы фермеров могут проводиться для обмена знаниями и опытом между фермерами из приграничных районов для поиска решений общих проблем, связанных с доступом к сельскому хозяйству и рынкам животноводства, ирригации, последствиям изменения климата, эрозии и сохранения земель. Можно обратиться за поддержкой к торговым палатам.

96. Для поддержки региональных организаций могут быть созданы региональные фермерские организации, которые помогут фрермерам из приграничных районов в наращивании социального капитала и предоставят платфрорму для их взаимодействия с другими фермерами по ту сторону границы.

\section{(v) Усилить роль частного сектора и гражданского общества}

97. В К Вонтексте ЦАРЭС частный сектор может играть важную роль в развитии приграничных сообществ и расширении контактов между людьми через границы, а также в качестве заинтересованной стороны, партнера и поставщика услуг для пограничных агентств. Например, в инициативах по управлению границами участие частного сектора может приносить пользу пограничным ведомствам посредством консультаций, сотрудничества и заключения контрактов. Некоторые инициативы, направленные на достижение этой цели, описаны выше. Дополнительные виды деятельности, которые могут быть выполнены, заключаются в следующем.

98. Может быть создана региональная рабочая группа по торговым палатам для поддержки торговых палат в продвижении деловых контактов, чьи исследования и аналитические заметки могут быть распространены Институтом ЦАРЭС и использованы в качестве инструментов политической защиты среди государств-членов дляпродвижения политики в интересах коммерции в регионе ЦАРЭС.

99. Ц Центры содействия торговле 61 могут быть созданы на существующих трансграничных рынках для обмена инфрормацией о торговой политике, таможенных пошлинах, инвестициях и торговых возможностях для содействия свободному перемещению торговцев, бизнесменов, капитала, товаров и услуг через границы.

100. Трансграничные бизнес-форумы могут проводиться для выявления административных и правовых барьеров, реформирования торговой политики, развития связей с фринансовыми учреждениями, содействия созданию совместных предприятий и обмена опытом и уроками из операций малого бизнеса.

61 Программа поддержки сел Белуджистана и Программа поддержки сел Сархада создали центры содействия торговле на пакистано-афганской границе в Хайберском проходе и Белуджистане, которые помогают торговцам и бизнесменам по обе стороны границы. 
101. Совместное обучение предпринимателей бизнес-планированию и управлению может помочь потенциальным предпринимателям по обе стороны границы развивать личные отношения, которые могут перерасти в совместные бизнес-предприятия. Также может быть рассмотрено создание фондов венчурного капитала для финансирования открытия нового бизнеса и предоставления оборотного капитала существующим предприятиям.

102. Организации гражданского общества (ОО) представляют интересы своих членов. Следовательно, их потенциал должен быть усилен для дальнейшего взаимодействия с государственным и частным секторами для реализации проектов и улучшения управления и подотчетности. Наращивание потенциала может осуществляться посредством обучения и создания сетей, ознакомительных поездок и обмена знаниями. Можно рассмотреть возможность организации местных и региональных фрорумов гражданского общества для региональных трансграничных программ.

103. Региональный форум гражданского общества ЦАРЭС мог бы стать важной институциональной платфрормой для продвижения взаимодействия между ОО стран-участниц для обмена знаниями. Им можно будет руководить совместно с другими партнерами - такими как Сеть развития Ага Хана (AKDN), Германское общество по международному сотрудничеству (GIZ), ЕС и Программа развития Организации Объединенных Наций (ПРООН). В число участвующих ОО могут входить молодежные объединения, ассоциации учителей и женские организации.

104. Ассоциация региональных туроператоров, региональный культурный форум, сетевой форум университетов ЦАРЭС и молодежный форум ЦАРЭС - это другие формы социальной организации.

\section{2. Устранение слабых сторон и проблем}

105. Высокий приоритет традиционно отдавался мерам по модернизации инфраструктуры и коммуникаций в регионе для преодоления естественных географических барьеров между странами ЦАРЭС, улучшения периферийного статуса приграничных сообществ и устранения транзитных препятствий в регионе ЦАРЭС. Тем не менее, дальнейшая поддержка также должна оказываться инициативам, которые конкретно развивают приграничные сообщества, как описано ниже.

\section{(i) Продвижение приграничных и трансграничных рынков в приграничных регионах}

106. Приграничные регионы на периферии стран-участниц ЦАРЭС считаются наименее развитыми сельскими регионами. В них наблюдается высокий уровень безработицы, низкая заработная плата и ограниченные возможности для формальной занятости. Участие в нефрормальной экономике часто является основным источником дохода приграничных сообществ. Предоставление государственных услуг является слабым. Приграничные и трансграничные рынки могут способствовать более тесному взаимодействию между общинами через границы и способствовать развитию субрегиональных ММСП. 62

62 Модель контролируемого содействия неформальной экономике сегодня актуальна для регионов КНР-Пакистан, Пакистан-Афганистан, Ферганской долины и приграничных регионов Афганистана и Таджикистана. 


\section{(ii) Увеличение участия микро-, малых и средних предприятий}

107. Потребность и потенциал развития ММСП в приграничных регионах различны для каждого региона в зависимости от уровня развития, моделей контактов и динамики трансграничной торговли, включая административные и нормативные барьеры. Для поддержки ММСП на приграничных территориях могут быть разработаны индивидуальные меры, включая информационные и консультационные сессии, общие и специальные тренинги, а также предоставление физических объектов - таких как бизнес-инкубаторы и выставочные площади.

108. Инновации и технологии могут повысить конкурентоспособность ММСП. Дальнейшая поддержка может быть оказана для определения потребностей и проблем ММСП в приграничных регионах, а также для создания необходимых условий, чтобы помочь им развиваться с помощью ИКТ.63

\section{(iii) Решение проблемы воздействия изменения климата на приграничные сообщества}

109. Изменение климата может усиливать нагрузку и ограничивать отношения между странами-членами ЦАРЭС. 64 Прогнозируемые последствия изменения климата будут создавать серьезную нагрузку на уже изношенные водохозяйственные системы и усугублять существующее ограниченное водоснабжение и качество воды в приграничных регионах ЦАРЭС. К неотъемлемым эффектам этой дополнительной нагрузки могут относиться проблемы, связанные с энергетической инфраструктурой, сельским хозяйством, продовольственной безопасностью и традиционным сельским хозяйством. «В отсутствие взаимного доверия и соглашений о совместном использовании функциональных ресурсов, отчаяние может усугублять исторические споры, раздувать предрассудки и перекладывать вину на невиновных», подвергая опасности и без того уязвимые и маргинализированные сообщества в приграничных регионах (сноска 64).

110. Программа ЦАРЭС может поддерживать региональный диалог по изменению климата и вовлекать центральные и местные правительства, частный сектор, международные организации и гражданское общество. Может быть проведен анализ соотношения выгод и затрат совместных структур для раннего предупреждения и оказания помощи при бедствиях, что, в конечном итоге, может способствовать обоснованию политической воли (сноска 64). Граждане конкретных приграничных регионов ЦАРЭС могут находиться ближе к службам помощи соседнего государства. «Однако трансграничное раннее предупреждение и оказание помощи при стихийных бедствиях еще не налажено» (сноска 64).

63 В рамках инициативы «Один пояс, один путь» создаются транснациональные цифровые и банковские сети, которые, следовательно, потенциально могут способствовать интеграции информационных технологий и финансовых услуг, обеспечивая более тесные контакты между людьми. Подписаны меморандумы о взаимопонимании в вопросах сотрудничества по Цифровому шелковому пути между КНР и 16 странами, 11 китайских банков открыли 71 филиал в 27 странах Пояса и Пути, а система трансграничного клиринга юаня охватывает 41 страну и регион. Xinhuanet. 2019 г. Подборка фрактов: новый прогресс в реализации инициативы «Один пояс, один путь». 19 марта.

64 Всемирный экономический форум. 2019 г. Изменение климата угрожает безопасности в Центральной Азии. Вот способы снизить риск. 25 января. 


\section{(iv) Усиление роли женщин в развитии приграничных сообществ}

111. Гендерное равенство и расширение прав и возможностей женщин являются предпосылками экономического роста и инклюзивного, справедливого и устойчивого развития. Усиление роли женщин и расширение их прав и возможностей как активных участников развития приграничных сообществ имеет хороший экономический смысл, поскольку ведет к сокращению масштабов нищеты, ускорению роста и большим благам для всего общества.

112. Таким образом, ЦАРЭС в рамках структуры, определенной в Гендерной стратегии ЦАРЭС до 2030 года, может поддерживать инициативы, направленные на усиление роли женщин в развитии приграничных сообществ, в дополнение к национальным и региональным усилиям по достижению гендерного равенства. Стратегии, открывающие дорогу женщинам в приграничных районах, включают поддержку в расширении экспортных секторов, в которых много женщин, и решение проблем, влияющих на предложение женской рабочей силы, таких как дискриминационные нормативные акты и законы по половому признаку и ограниченный доступ женщин к основным услугам и активам, включая образование и тренинги, сети, транспорт, инфрраструктуру, кредиты, землю, производственным сельскохозяйственные ресурсы и ИКТ. ЦАРЭС также может рассмотреть возможность предоставления поддержки для улучшения предотвращения и выявления торговли людьми, усиления защиты и продвижения прав человека, создания более представительных институтов управления границами и усиления надзора со стороны гражданского общества. 65 Для определения конкретных инициатив ЦАРЭС может способствовать обсуждению в фокус-группах различных секторов (например, женщин-торговцев) среди женщин, живущих в приграничных районах, чтобы делиться своим предпринимательским опытом.

65 А. Маккей. 2008 г. Управление границами и гендерная проблематика. В публикации под редакцией Меган Бастик и Кристин Валасек. Пособие по реформе сектора гендерной проблематики и безопасности. Женева: DCAF, OБCE/ БДИПЧ, Международный учебный и научно-исследовательский институт по улучшению положения женщин (МУНИУЖ) $\mathrm{OOH}$. 


\section{6. Рекомендации для ЦАРЭС}

113. Это исследование определяет серию рекомендаций, чтобы ЦАРЭС могла играть активную роль в расширении приграничного сотрудничества в приграничных регионах, на основе уроков, извлеченных из передового международного опыта, и результатов SWOT-анализа. Эти рекомендации могут быть реализованы путем принятия подхода, ориентированного на сообщества, и сгруппированы по трем категориям:

(i) Отраслевые рекомендации. Предлагаемые инициативы относятся к конкретным секторам в рамках пяти операционных кластеров ЦАРЭС. Рекомендуется, чтобы в планируемых инициативах ЦАРЭС уделялось внимание реализации потенциала для регионального сотрудничества посредством продвижения трансграничного сотрудничества сообществ в этих секторах и областях. Дополнительный набор рекомендаций относится к изменению климата как сквозной теме для остальных секторов.

(ii) Рекомендации на институциональном уровне. Этот комплект включает в себя инициативы по укреплению потенциала местных институтов приграничного сотрудничества.

(iii) Рекомендации по гендерному равенству. В соответствии с Гендерной стратегией ЦАРЭС 2030, эти инициативы направлены на усиление роли женщин в развитии приграничных сообществ.

114. Предлагаемые рекомендации по обеспечению связанности между людьми и развитию приграничных сообществ в регионе ЦАРЭС резюмированы в Таблице 3.

\section{Таблица 3: Краткое изложение рекомендаций по развитию приграничных сообществ}

А. Рекомендации для конкретных секторов

\begin{tabular}{|c|c|}
\hline Сектор & Рекомендации \\
\hline $\begin{array}{l}\text { Экономический } \\
\text { и фринансовый } \\
\text { сектор }\end{array}$ & $\begin{array}{l}\text { - Оказывать техническую и фринансовую поддержку ММСП в приграничных } \\
\text { районах с целью создания благоприятных условий для продвижения } \\
\text { трансграничного бизнеса посредством обучения и установления партнерских } \\
\text { отношений с микрофинансовыми организациями и коммерческими банками. }\end{array}$ \\
\hline Торговля & $\begin{array}{l}\text { - Поддерживать создание центров по упрощению процедур торговли в целевых } \\
\text { районах. } \\
\text { - Сформулировать диагностические исследования механизмов координации и } \\
\text { протоколов пограничных ведомств для улучшения систем управления границами. } \\
\text { - Создать рабочую группу по торговым палатам для поддержки торговых палат } \\
\text { региона и развития деловых контактов. } \\
\text { - Проводить трансграничные бизнес-срорумы для усиления роли частного сектора. }\end{array}$ \\
\hline
\end{tabular}


Продолжение Таблицы 3

\begin{tabular}{|c|c|}
\hline Сектор & Рекомендации \\
\hline Туризм & $\begin{array}{l}\text { - Создать региональную ассоциацию туроператоров для обмена знаниями о } \\
\text { продвижении устойчивого и общинного туризма в приграничных регионах. } \\
\text { - Провести Форум по туризму и культуре ЦАРЭС для содействия созданию } \\
\text { сетей и партнерству между государственными ичастными заинтересованными } \\
\text { сторонами - в том числе, из приграничных районов. }\end{array}$ \\
\hline $\begin{array}{l}\text { Сельское } \\
\text { хозяйство }\end{array}$ & $\begin{array}{l}\text { - Сформулировать исследование региональных и трансграничных } \\
\text { сельскохозяйственных цепочек добавленной стоимости для сельского } \\
\text { хозяйства в ЦАРЭС. } \\
\text { - Укрепить политику и институты для эффективного управления } \\
\text { трансграничными водными ресурсами. } \\
\text { - Обучать фермеров эфффективному использованию воды и сопутствующим } \\
\text { технологиям. } \\
\text { - Проводить региональные инвестиционные конференции, торговые ярмарки и } \\
\text { форумы фермеров для обмена знаниями и опытом, в том числе с участниками } \\
\text { из приграничных районов. Это может привести к созданию региональных } \\
\text { фермерских организаций. }\end{array}$ \\
\hline Здравоохранение & $\begin{array}{l}\text { - Создать центрынеотложной медицинской помощив отобранныхприграничных } \\
\text { пунктах для оказания базовой и неотложной помощи местным жителям и } \\
\text { приграничным общинам. }\end{array}$ \\
\hline Образование & $\begin{array}{l}\text { - Провести сетевой форум университетов ЦАРЭС и молодежный форум } \\
\text { ЦАРЭС для расширения прав и возможностей молодежи, проживающей в } \\
\text { приграничных районах. } \\
\text { - Поддерживать трансграничные программы для молодежных организаций, } \\
\text { студенческие обмены и совместные исследовательские проекты. } \\
\text { Поддерживать курсы технического и профессионального обучения в рамках } \\
\text { трансграничных программ. }\end{array}$ \\
\hline $\begin{array}{l}\text { Изменение } \\
\text { климата }\end{array}$ & $\begin{array}{l}\text { - Сформулировать анализ затрат и выгод совместных структур для раннего } \\
\text { предупреждения и оказания помощи при бедствиях в приграничных районах. } \\
\text { - Вести региональный диалог по вопросам изменения климата с центральными } \\
\text { правительствами и местными органами власти, частным сектором, } \\
\text { международными организациями и гражданским обществом, включая } \\
\text { приграничные сообщества. } \\
\text { - Проводить учебные программы по экологически чистой энергетике, } \\
\text { устойчивому управлению ресурсами, экотуризму и продвижению } \\
\text { энергоэффективных технологий в приграничных районах. }\end{array}$ \\
\hline
\end{tabular}

В. Рекомендации институционального уровня

- Сформулировать обзорное исследование трансграничных институтов и политики развития приграничных сообществ.

- Содействовать партнерству между ЦАРЭС и надежными и приемлемыми для банков трансграничными учреждениями.

- Оказывать правительствам поддержку в разработке правовых рамок для поддержки трансграничных программ.

- Поддерживать инициативы по повышению осведомленности в центральных и региональных органах власти о создании благоприятных институциональных рамок для трансграничного развития сообществ с целью содействия успешному государственно-частному сотрудничеству в этой области.

- Обеспечивать наращивание потенциала и финансовой поддержки для ОО и частного сектора, работающих в приграничных районах.

- Провести форум гражданского общества ЦАРЭС для содействия взаимодействию между людьми и ОО стран-членов - в том числе, из приграничных районов. 
Продолжение Таблицы 3

С. Рекомендации по гендерному равенству

- Сформулировать исследование, чтобы подвести итоги деятельности местных организаций в приграничных районах, которые оказывают поддержку уязвимым группам - таким как женщины, молодежь и люди с особыми потребностями.

- Оказывать правительствам поддержку в разработке гендерной политики, обеспечивающей женщинам, живущим в приграничных регионах, доступ к достойной работе, экономическим возможностям, образованию и обучению, услугам здравоохранения, ИКТ, инфраструктуре и государственным услугам; и участвовать в процессах принятия решений.

- Содействовать политическому диалогу на региональном и межстрановом уровнях, чтобы позволить заинтересованным сторонам со всего региона учиться на опыте друг у друга и применять передовые методы для расширения прав и возможностей женщин и учета гендерной проблематики в приграничных регионах.

- Проводить женские форумы и конференции для обмена знаниями и передовым опытом в различных секторах - таких как торговля. Содействовать установлению контактов между женщинами-предпринимателями из приграничных регионов.

- Обучать пограничников минимизации дискриминации по половому признаку на границах и усилить защиту и продвижение прав человека.

ЦАРЭС = Центральноазиатское региональное экономическое сотрудничество, ОО = организация гражданского общества, ИКТ = информационные и коммуникационные технологии, ММСП = микро-, малые и средние предприятия. Источник: Секретариат ЦАРЭС

115. АБР и другие партнеры по развитию ЦАРЭС могли бы предоставить техническую помощь в качестве начала для содействия диалогу и подготовки надежных проектных предложений для углубления сотрудничества с сообществами в регионе. Институт ЦАРЭС также может поддержать проведение исследований, тренингов и распространение данных, касающихся трансграничного сотрудничества сообществ.

116. Воздействие приведенных выше рекомендаций может способствовать продвижению связанности между людьми в регионе и развитию приграничных сообществ, что, в конечном итоге, улучшит жизнь миллионов людей и улучшит источники средств к существованию для нынешнего и будущих поколений. Во время составления данного отчета мир борется с пандемией COVID-19, поэтому некоторые рекомендации могут показаться неэффективными в ближайшее время. Однако кризис также предоставляет уникальную возможность для дальнейшего развития предлагаемых инициатив, которые будут реализованы в 2021 году и в последующий период. 


\title{
Приложения
}

\section{Приложение 1. Консультации со странами}

\begin{abstract}
Азербайджан и Грузия
Граница между Азербайджаном и Грузией была выбрана для полевой миссии, потому что эти две страны являются частью Программы поддержки территориального сотрудничества Восточного партнерства, финансируемой Европейским союзом (EC). Ценные уроки можно извлечь из подхода ЕС к развитию трансграничных сообществ. Программа территориального сотрудничества в рамках восточного партнерства (ЕАРТC) - это совместная политическая инициатива, направленная на углубление и укрепление отношений между ЕС, его государствами-членами и шестью его восточными соседями: Арменией, Азербайджаном, Беларусью, Грузией, Молдовой и Украиной.
\end{abstract}

Команда экспертов Программы Центральноазиатского регионального экономического сотрудничества (ЦАРЭС) встретилась с экспертами Германского общества по международному сотрудничеству (Deutsche Gesellschaft für Internationale Zusammenarbeit, GIZ), исполнительным агентством ЕАРТC в Грузии и Азербайджане. Некоторые из извлеченных уроков заключаются в следующем:

(i) Инициативы регионального сотрудничества должны согласовываться с политикой центрального правительства, а национальные и местные администрации нуждаются в поддержке.

(ii) Механизмы выплаты донорских средств должны быть адаптированы к национальным и международным нормам перевода средств.

(iii) Обмен опытом регионального сотрудничества полезен для развития сетей заинтересованных сторон, включая информационные кампании для бенефициаров.

(iv) Инициативы, способствующие установлению контактов и интеграции между людьми, эфрфективны, хотя рабочая среда является строгой.

ЕАРТС реализовала шесть проектов на границе между Азербайджаном и Грузией. 


\section{Проекты территориального сотрудничества в рамках Восточного партнёрства, реализуемые на азербайджано-грузинской границе}

\begin{tabular}{|l|l|}
\hline Главный бенефициар ЕАРТС (ведущий партнер) & \multicolumn{1}{c|}{ Название проекта ЕАРТС } \\
\hline Союз азербайджанских женщин Грузии & $\begin{array}{l}\text { Расширение прав и возможностей молодежи через } \\
\text { жизненные ценностиа }\end{array}$ \\
\hline Общественный образовательный центр Кода & $\begin{array}{l}\text { Гражданское общество за развитие и } \\
\text { сотрудничество: повышение туристического } \\
\text { потенциала в приграничных регионах } \\
\text { Азербайджана и Грузии }\end{array}$ \\
\hline Гражданское развитие & Синергия молодых предпринимателей (YES!)c \\
\hline Гянджинская ассоциация агробизнеса & $\begin{array}{l}\text { Внедрение экологически чистой борьбы с } \\
\text { вредителями для биологической защиты } \\
\text { сельскохозяйственных культур в приграничных } \\
\text { районах }\end{array}$ \\
\hline $\begin{array}{l}\text { Общественное объединение Гянджинский } \\
\text { евроатлантический инфрормационный центр }\end{array}$ & $\begin{array}{l}\text { Укрепление трансграничного партнерства в } \\
\text { предоставлении новых социальных услуг для } \\
\text { детей с ограниченными возможностями в Гянджа- } \\
\text { Газахском районе Азербайджана и регионе Квемо- } \\
\text { Картли в Грузиие }\end{array}$ \\
\hline Собрание муниципалитета Телави & $\begin{array}{l}\text { Навыки, необходимые для трудоустройства } \\
\text { молодых людей }\end{array}$ \\
\hline
\end{tabular}

a ЕАРТС. 2018 г. Расширение прав и возможностей молодежи через жизненные ценности. Проект был направлен на расширение возможностей молодых людей, живущих в приграничных регионах, способствовать позитивным социальным изменениям и конструктивному сотрудничеству путем создания жизненно важных школьных центров и проведения совместных культурных, спортивных и туристических мероприятий.

b ЕАРТС. 2018 г. Гражданское общество за развитие и сотрудничество: повышение туристического потенциала в приграничных регионах Азербайджана и Грузии.

c EAPTC. 2018 г. Сеть «Синергия молодых предпринимателей (YES!) для приграничного сотрудничества между Грузией и Азербайджаном».

d ЕАРТС. 2018 г. Внедрение экологически чистой борьбы с вредителями для биозащиты сельскохозяйственных культур в приграничных районах Азербайджана (Шеки-Загатала) и Грузии (Лагодехи).

e ЕАРТC. 2018 г. Укрепление трансграничного партнерства в предоставлении новых социальных услуг для детей с ограниченными возможностями в Гянджа-Газахском районе Азербайджана и регионе Квемо Картли Грузии.

f ЕАРТC. 2018 г. Навыки трудоустройства для молодых людей в муниципалитете Шеки и Телави.

ЕАРТС = Территориальное сотрудничество в рамках Восточного партнерства.

Источник: Территориальное сотрудничество в рамках Восточного партнерства (ЕАРTC). 2018 г. Программа территориального сотрудничества в рамках Восточного партнёрства.

Помимо вышеуказанных бенефициаров или ведущих партнеров миссия также встретилась с агентствами, связанными с частным сектором, такими как Торговая палата. Результаты этих встреч были включены в исследование.

\section{> Китайская Народная Республика и Монголия}

Приграничная зона между Китайской Народной Республикой (КНР) и Монголией была выбрана для проведения некоторых полевых консультаций, учитывая, что в 2014 году обе страны повысили двусторонние связи до уровня всеобъемлющего стратегического партнерства. В экономическом сотрудничестве между этими двумя странами приоритет отдается природным ресурсам и инфраструктуре. Это партнерство также направлено на усиление политической коммуникации для укрепления сотрудничества в области безопасности. В 2014 году в 
рамках инициативы «Один пояс, один путь» был поддержан экономический коридор КНР Монголия - Российская Федерация по созданию зон свободной торговли и экономического сотрудничества в приграничных городах между этими странами. ${ }^{1}$

В Улан-Баторе состоялись встречи со следующими организациями: (i) Институт Конфуция при Национальном университете Монголии; (ii) Монгольская национальная торговопромышленная палата; (iii) Министерство природы, окружающей среды и туризма Монголии; (iv) Всемирный банк; и (v) Партнерство по действиям в области зеленой экономики в Монголии.

В Автономном районе Внутренняя Монголия (КНР) состоялись встречи со следующими организациями: (i) Департамент транспорта автономного района Внутренней Монголии, (ii) Совет Китая по развитию международной торговли; и (iii) Зона приграничного экономического сотрудничества Эренхот.

\section{$>\quad$ Таджикистан}

Во время своей миссии в Таджикистан 21-26 мая 2018 года команда Азиатского банка развития (АБР) встретилась со следующими донорами и партнерами по реализации трансграничных программ: Сетью развития Ага Хана (AKDN), Японским агентством международного сотрудничества, Банком развития KfW, Программой развития Организации Объединенных Наций (ПРООН), Университетом Центральной Азии, Ассоциацией предпринимателей и горных фрермеров, Программой поддержки развития горных сообществ Кыргызстана, Службой здравоохранения Ага Хана, организаторами фестиваля «Крыша мира» и трансграничными торговцами. Полевые наблюдения за деятельностью в рамках приграничной программы также были проведены во время рабочей поездки миссии АБР.

Группа также встретилась с руководителями представительств Фонда Ага Хана, JICA, $\mathrm{KfW}$ и ПРООН в Душанбе, чтобы извлечь уроки из их трансграничных программ, прежде чем отправиться в четырехдневную рабочую поездку по Хатлонской области и ГорноБадахшанской автономной области, чтобы ознакомиться с трансграничными мероприятиями, реализуемыми партнерами.

Результаты этих встреч были включены в исследование.

1 Йи Чен. 2018 г. Инвестиционная конкуренция Китая и Японии в Монголии. The Diplomat. 1 августа. 


\section{Приложение 2. Въездные визы между странами ЦАРЭС}

\begin{tabular}{|c|c|c|c|c|c|c|c|c|c|c|c|}
\hline$\frac{И_{3} \rightarrow}{\mathrm{B} \downarrow}$ & АФГ & A3E & KHP & ГРУ & KA3 & КЫР & MOH & ПАК & ТАД & TKM & У3Б \\
\hline АФГ & & C & C & C & C & C & C & C & C & C & C \\
\hline A3E & C & & $A / B$ & $\mathrm{~F}$ & $\mathrm{~F}$ & $\mathrm{~F}$ & C & B & $\mathrm{F}$ & B & $\mathrm{F}$ \\
\hline KHP & C & C & & C & $\mathrm{Ca}^{\mathrm{a}}$ & C & $\mathrm{F}$ & C & C & C & C \\
\hline ГРУ & C & $F$ & B & & $\mathrm{F}$ & $F$ & B & C & $F$ & $\mathrm{~F}$ & $F$ \\
\hline KA3 & C & $\mathrm{F}$ & $B / C$ & $\mathrm{~F}$ & & $\mathrm{~F}$ & $\mathrm{~F}$ & C & $\mathrm{F}$ & C & $\mathrm{F}$ \\
\hline КЫР & B & $\mathrm{F}$ & B & $\mathrm{F}$ & $\mathrm{F}$ & & $\mathrm{F}$ & B & $\mathrm{F}$ & B & $\mathrm{F}$ \\
\hline MOH & C & C & C & C & $\mathrm{F}$ & $\mathrm{F}$ & & C & C & C & C \\
\hline ПАК & C & $A / B$ & B & B & B & B & B & & $A / B$ & B & B \\
\hline ТАД & B & $F$ & B & $\mathrm{F}$ & $F$ & $F$ & C & B & & $A / B$ & $\mathrm{~F}$ \\
\hline TKM & C & C & $\mathrm{A} / \mathrm{C}$ & C & C & C & C & C & C & & C \\
\hline У3Б & B & $F$ & $\mathrm{~F}$ & $\mathrm{~F}$ & $\mathrm{~F}$ & $\mathrm{~F}$ & $\mathrm{~F}$ & B & $\mathrm{F}$ & B & \\
\hline
\end{tabular}

АФГ = Афганистан, АЗЕ = Азербайджан, ЦАРЭС = Центральноазиатское региональное экономическое сотрудничество, КНР = Китайская Народная Республика, ГРУ = Грузия, КАЗ = Казахстан, КЫР = Кыргызская Республика, $\mathrm{MOH}=$ Монголия, ПАК= Пакистан, ТАД = Таджикистан, ТКМ = Туркменистан, УЗБ = Узбекистан. Примечания:

1. $\mathrm{A}$ = виза по прибытии, $\mathrm{B}=$ право на электронную визу, $\mathrm{C}=$ виза, которую необходимо получить до поездки, $\mathrm{F}=$ безвизовый режим.

2. Все результаты относятся к владельцам обычным паспортов.

а Безвизовый въезд для граждан Казахстана в провинцию Хайнань (КНР).

Источник: вебсайт Passport Index. Сравнение паспортов (по состоянию на 1 июля 2020 г.). 


\section{Приложение 3. Основные пункты пропуска через границу между странами ЦАРЭС}

\begin{tabular}{|c|c|c|c|c|c|c|c|c|}
\hline $\begin{array}{c}\text { Страна } \\
1\end{array}$ & $\begin{array}{l}\text { Страна } \\
2\end{array}$ & $\begin{array}{l}\text { Расширение } \\
\text { границы } \\
\text { (км) }\end{array}$ & № & $\begin{array}{l}\text { Название пункта } \\
\text { пересечения }\end{array}$ & $\begin{array}{l}\text { Расположение в } \\
\text { стране } 1\end{array}$ & $\begin{array}{l}\text { Расположение в } \\
\text { стране } 2\end{array}$ & $\begin{array}{l}\text { Этнические } \\
\text { группы }\end{array}$ & Дополнительная информация \\
\hline \multirow{5}{*}{ A3E } & \multirow{5}{*}{ ГРу } & \multirow{5}{*}{480} & 1 & $\begin{array}{l}\text { Красный мост } \\
\text { (Цители Хиди) }\end{array}$ & $\begin{array}{l}\text { Газахский район, } \\
\text { село Шихли ॥ }\end{array}$ & $\begin{array}{l}\text { Квемо Картли, } \\
\text { Марнеульский } \\
\text { район, село Керчь- } \\
\text { Муганло }\end{array}$ & $\begin{array}{l}\text { Грузины: } 217 \\
305 \text { человек } \\
(51,25 \%)\end{array}$ & \multirow{4}{*}{$\begin{array}{l}\text { Эти пять пунктов пропуска } \\
\text { позволяют перевозить все типы } \\
\text { пассажиров и грузов. } \\
\text { Горнодобывающая } \\
\text { промышленность играет важную } \\
\text { роль в приграничных регионах } \\
\text { между Грузией и Азербайджаном. } \\
\text { Приграничные рынки собирают } \\
\text { сельскохозяйственную и } \\
\text { кустарную продукцию. }\end{array}$} \\
\hline & & & 2 & $\begin{array}{l}\text { Садыхлы (АЗЕ) } \\
\text { или Вахтангиси } \\
\text { (ГРУ) }\end{array}$ & $\begin{array}{l}\text { Агстафиинский } \\
\text { район, село } \\
\text { Садыхлы }\end{array}$ & $\begin{array}{l}\text { Квемо-Картли, } \\
\text { село Вахтангиси }\end{array}$ & $\begin{array}{l}\text { Азербайджанцы: } \\
177032 \text { человека } \\
(41,75 \%)\end{array}$ & \\
\hline & & & 3 & $\begin{array}{l}\text { Балакан (АЗЕ) или } \\
\text { Лагодехи (ГРУ) }\end{array}$ & $\begin{array}{l}\text { Балаканский } \\
\text { район }\end{array}$ & $\begin{array}{l}\text { Кахетинский } \\
\text { регион, } \\
\text { Лагодехский район } \\
\text { (муниципалитет), } \\
\text { село Мацими }\end{array}$ & $\begin{array}{l}\text { Армяне: } \\
21500 \text { человек } \\
(5,07 \%)\end{array}$ & \\
\hline & & & 4 & $\begin{array}{l}\text { Муганло (АЗЕ) или } \\
\text { Самтацкаро (ГРУ) }\end{array}$ & Газахский район & $\begin{array}{l}\text { Муниципалитет } \\
\text { Дедоплисцкаро, } \\
\text { село Самтацкаро }\end{array}$ & $\begin{array}{l}\text { Греки: } \\
2631 \text { человек } \\
(0,62 \%)\end{array}$ & \\
\hline & & & 5 & $\begin{array}{l}\text { Алмали (АЗЕ) или } \\
\text { Гардабани (ГРУ) }\end{array}$ & Газахский район & $\begin{array}{l}\text { Марнеульский } \\
\text { муниципалитет, } \\
\text { село } \\
\text { железнодорожная } \\
\text { станция Садахло- } \\
\text { вокзал }\end{array}$ & $\begin{array}{l}\text { Русские: } \\
2113 \text { человек } \\
(0,49 \%)\end{array}$ & $\begin{array}{l}\text { Алмалы или Гардабани - } \\
\text { железнодорожный переезд. }\end{array}$ \\
\hline \multirow{6}{*}{ АФГ } & & & 1 & Перевал Вахджир & Горный хребет & Горный хребет & - & \multirow{2}{*}{$\begin{array}{l}\text { Эти два перевала закрыты из-за } \\
\text { закрытия для въезда посетителей } \\
\text { долины Чалачигу на стороне } \\
\text { КНР. Местным жителям и } \\
\text { пастухам, проживающим на этой } \\
\text { территории, доступ разрешен. }\end{array}$} \\
\hline & KHP & 76 & 2 & $\begin{array}{l}\text { Перевал } \\
\text { Тегермансу }\end{array}$ & Горный хребет & Горный хребет & - & \\
\hline & & & 1 & $\begin{array}{l}\text { Торхам } \\
\text { (Хайберский } \\
\text { проход и район } \\
\text { Моманд Дара) }\end{array}$ & $\begin{array}{l}\text { Джелалабад, } \\
\text { Нангахар }\end{array}$ & Пешавар & \multirow{3}{*}{$\begin{array}{l}\text { Белуджи, синдхи } \\
\text { и пуштуны } \\
\text { - основные } \\
\text { племена с } \\
\text { несколькими } \\
\text { более мелкими } \\
\text { племенами, } \\
\text { такими как } \\
\text { Утманхель, } \\
\text { Мохманд, } \\
\text { Таркани и } \\
\text { Сафи. }\end{array}$} & \multirow{3}{*}{$\begin{array}{l}\text { Здесь } 18 \text { неосицииальных } \\
\text { транспортных переходов и около } \\
235 \text { судоходных переходов. } \\
\text { Имеется восемь официальных } \\
\text { пунктов пропуска на границе } \\
\text { между Афрганистаном и } \\
\text { Пакистаном; Торкхам и } \\
\text { Чаман - Спин Болдак имеют } \\
\text { статус международных } \\
\text { пунктов пропуска. Остальные } \\
\text { пункты пропуска являются } \\
\text { двусторонними: Аранду (Читрал), } \\
\text { Гурсал (Баджаур), Перевал } \\
\text { Нава (Моманд), Харлачи } \\
\text { (Кур-Рам), Гулам Хан (Северный } \\
\text { Вазиристан), Ангур Адда } \\
\text { (Южный Вазиристан) и Чаман } \\
\text { (Белуджистан). }\end{array}$} \\
\hline & & & 2 & $\begin{array}{l}\text { Спин Болдак (Веш } \\
\text { - Чаман) }\end{array}$ & $\begin{array}{l}\text { Провинция } \\
\text { Кандагар }\end{array}$ & $\begin{array}{l}\text { Кветта, } \\
\text { Белуджистан }\end{array}$ & & \\
\hline & ПАК & 2430 & 3 & Гулам Хан & Гурбаз, Хост & $\begin{array}{l}\text { Мираншах, } \\
\text { Северный } \\
\text { Вазиристан }\end{array}$ & & \\
\hline & ТАД & 1206 & 1 & $\begin{array}{l}\text { Ширхан Бандар } \\
\text { (АФГ) - Панджи } \\
\text { Пойон (ТАД) }\end{array}$ & Кундуз & $\begin{array}{l}\text { Кумсангирский } \\
\text { район }\end{array}$ & $\begin{array}{l}\text { Таджики, } \\
\text { туркмены и } \\
\text { узбеки }\end{array}$ & $\begin{array}{l}\text { По обе стороны этой } \\
\text { границы можно обнаружить } \\
\text { многочисленные поселения. На } \\
\text { афрганской стороне находятся } \\
\text { Багри Кол, Колух Теппе, Ширхан } \\
\text { Бандар, Шах Раван, Чичке. } \\
\text { Дашт-э-Кала, Квахан, Хоссрав, } \\
\text { Арахат и Ишкашим. На } \\
\text { таджикской стороне можно найти } \\
\text { Айвадж, Панджи Пойон, Дасти, } \\
\text { Пяндж, Паркхар, Кишти Ройен, } \\
\text { Калаи-Хумб, Кеврон, Рушон, } \\
\text { Бажду Павдив, Хорог, Ишкошим } \\
\text { и Синиб. }\end{array}$ \\
\hline
\end{tabular}


Продолжение Таблицы в Приложении 3

\begin{tabular}{|c|c|c|c|c|c|c|c|c|}
\hline $\begin{array}{c}\text { Страна } \\
1\end{array}$ & $\begin{array}{l}\text { Страна } \\
2\end{array}$ & $\begin{array}{l}\text { Расширение } \\
\text { границы } \\
\text { (км) }\end{array}$ & № & $\begin{array}{l}\text { Название пункта } \\
\text { пересечения }\end{array}$ & $\begin{array}{l}\text { Расположение в } \\
\text { стране } 1\end{array}$ & $\begin{array}{l}\text { Расположение в } \\
\text { стране } 2\end{array}$ & $\begin{array}{l}\text { Этнические } \\
\text { группы }\end{array}$ & Дополнительная информация \\
\hline \multirow{5}{*}{$\begin{array}{l}\text { АФГ } \\
\text { (продолж } \\
\text { ение) }\end{array}$} & & & 2 & $\begin{array}{l}\text { Шоссе Султан } \\
\text { (АФГ) или шоссе } \\
\text { Ишкашим } \\
\text { (ТАД) }\end{array}$ & Бадахшан & $\begin{array}{l}\text { Ишкашимский } \\
\text { район }\end{array}$ & $\begin{array}{l}\text { Таджики, } \\
\text { туркмены и } \\
\text { узбеки }\end{array}$ & $\begin{array}{l}\text { Дашт-э-Кала, Квахан, Хоссрав, } \\
\text { Арахат и Ишкашим. На } \\
\text { таджикской стороне можно } \\
\text { найти Айвадж, Панджи Пойон, } \\
\text { Дасти, Пяндж, Паркхар, Кишти } \\
\text { Ройен, Калаи-Хумб, Кеврон, } \\
\text { Рушон, Бажду Павдив, Хорог, } \\
\text { Ишкошим и Синиб. }\end{array}$ \\
\hline & \multirow[b]{2}{*}{ TKM } & \multirow[b]{2}{*}{744} & 1 & $\begin{array}{l}\text { Торгунди (АФГ) - } \\
\text { Серхетабат (ТКМ) } \\
\text { (автомобильный и } \\
\text { железнодорожный) }\end{array}$ & $\begin{array}{l}\text { Герат } \\
\text { Кошк } \\
\text { (Администрация } \\
\text { Герата) }\end{array}$ & Ёлотен & & \multirow{2}{*}{$\begin{array}{l}\text { Возле границы с } \\
\text { Афганистаном находятся } \\
\text { несколько поселений, включая } \\
\text { Муричак, Джаладжин, } \\
\text { Мухаммад Таши, Солтан } \\
\text { Робат, Яка Хаджи, Бай } \\
\text { Хан, Кавк, Хамьяб, Каркин } \\
\text { и Келефт. По туркменскую } \\
\text { сторону границы можно } \\
\text { обнаружить такие поселения } \\
\text { как Серхетабат, Башбеден, } \\
\text { Ходжали, Ымамназар и } \\
\text { Босага. }\end{array}$} \\
\hline & & & 2 & $\begin{array}{l}\text { Акина (АФГ) } \\
\text { - Ымамназар } \\
\text { (ТКМ) (ж/д) }\end{array}$ & $\begin{array}{l}\text { Провинция } \\
\text { Фарьяб }\end{array}$ & $\begin{array}{l}\text { Лебапский } \\
\text { велаят }\end{array}$ & & \\
\hline & \multirow[b]{2}{*}{ УзБ } & \multirow[b]{2}{*}{137} & 1 & $\begin{array}{l}\text { Хайратан (АФГ) } \\
\text { - Термез (УЗБ) } \\
\text { (автодорога) }\end{array}$ & \multirow[t]{2}{*}{$\begin{array}{l}\text { Балхская } \\
\text { область }\end{array}$} & \multirow[t]{2}{*}{$\begin{array}{l}\text { Термезская } \\
\text { область }\end{array}$} & & $\begin{array}{l}\text { Река Амударья разделяет две } \\
\text { страны. }\end{array}$ \\
\hline & & & 2 & $\begin{array}{l}\text { Хайратан (АФГ) } \\
\text { - Галаба (UZB) } \\
\text { (ж/д) }\end{array}$ & & & & $\begin{array}{l}\text { Поселения недалеко от } \\
\text { границы в Афганистане - } \\
\text { Дали, Калдар и Хайратан. } \\
\text { Со стороны Узбекистана } \\
\text { находится Термез. }\end{array}$ \\
\hline \multirow{5}{*}{ KHP } & \multirow{5}{*}{ КАЗ } & \multirow{5}{*}{1533} & 1 & $\begin{array}{l}\text { Хоргос/Нур } \\
\text { Жолы }\end{array}$ & Урумчи & Алматы & \multirow[t]{5}{*}{$\begin{array}{l}\text { КНР: уйгуры, } \\
\text { казахи и } \\
\text { ханьские } \\
\text { китайцы } \\
\text { КАЗ: Казахстан }\end{array}$} & $\begin{array}{l}\text { C } 2018 \text { года бывший } \\
\text { пограничный переход Хоргос } \\
\text { больше не действует и теперь } \\
\text { функционирует только как } \\
\text { особая экономическая зона. }\end{array}$ \\
\hline & & & 2 & $\begin{array}{l}\text { Майкапчагай- } \\
\text { Джеминай }\end{array}$ & $\begin{array}{l}\text { Синьцзян- } \\
\text { Уйгурский } \\
\text { автономный } \\
\text { район }\end{array}$ & $\begin{array}{l}\text { Северный } \\
\text { Казахстан }\end{array}$ & & $\begin{array}{l}\text { Международный центр } \\
\text { приграничного сотрудничества } \\
\text { «Хоргос» открылся в } 2011 \\
\text { году и является безвизовой } \\
\text { зоной. Жители по обе стороны } \\
\text { границы могут торговать } \\
\text { и пользоваться местными } \\
\text { развлечениями а }\end{array}$ \\
\hline & & & 3 & Бахты-Таченг & Таченг & Бахты & & \multirow{3}{*}{$\begin{array}{l}\text { К поселениям недалеко от } \\
\text { границы в КНР относятся: } \\
\text { Таченг, Хуочэн и Хоргос. В } \\
\text { Казахстане это - Алексеево, } \\
\text { Таунчанг, Акшокы, Бахты, } \\
\text { Достык, Алмалы, Хоргос, } \\
\text { Кольжат, Сарыбастау, Сумбе и } \\
\text { Нарынколь. }\end{array}$} \\
\hline & & & 4 & $\begin{array}{l}\text { Достык/Дружба - } \\
\text { Алашанькоу }\end{array}$ & Алашанькоу & Достык & & \\
\hline & & & 5 & $\begin{array}{l}\text { Калджат } \\
\text { (Калжат) - Порт } \\
\text { Дулата }\end{array}$ & Калджат & Дулата & & \\
\hline
\end{tabular}


Продолжение Таблицы в Приложении 3

\begin{tabular}{|c|c|c|c|c|c|c|c|c|}
\hline $\begin{array}{c}\text { Страна } \\
1\end{array}$ & $\begin{array}{c}\text { Страна } \\
2\end{array}$ & $\begin{array}{l}\text { Расширение } \\
\text { границы } \\
\text { (км) }\end{array}$ & № & $\begin{array}{c}\text { Название пункта } \\
\text { пересечения }\end{array}$ & $\begin{array}{c}\text { Расположение в } \\
\text { стране } 1\end{array}$ & $\begin{array}{c}\text { Расположение в } \\
\text { стране } 2\end{array}$ & $\begin{array}{l}\text { Этнические } \\
\text { группы }\end{array}$ & Дополнительная информация \\
\hline \multirow{9}{*}{$\begin{array}{c}\text { КНР } \\
\text { (продолж } \\
\text { ение) }\end{array}$} & \multirow[b]{2}{*}{ кЫР } & \multirow[b]{2}{*}{858} & 1 & $\begin{array}{l}\text { Перевал } \\
\text { Иркештам: } \\
\text { Ош-Кашгар }\end{array}$ & Кашгар & Ош & $\begin{array}{l}\text { КГЗ: таджики, } \\
\text { кыргызстанские } \\
\text { немцы }\end{array}$ & \multirow{2}{*}{$\begin{array}{l}\text { Кашгар исторически служил } \\
\text { торговым центром и когда- } \\
\text { то был крупным узлом на } \\
\text { Шелковом пути. В В } 2010 \text { году } \\
\text { город был преобразован в } \\
\text { особую экономическую зону - } \\
\text { единственный город на западе } \\
\text { КНР, удостоенный этой чести. }\end{array}$} \\
\hline & & & 2 & $\begin{array}{l}\text { Перевал } \\
\text { Торугарт }\end{array}$ & $\begin{array}{l}\text { Синьцзян- } \\
\text { Уйгурский } \\
\text { автономный } \\
\text { район }\end{array}$ & $\begin{array}{l}\text { Нарынская } \\
\text { область }\end{array}$ & $\begin{array}{l}\text { КНР: уйгуры } \\
\text { кыргызы } \\
\text { и ханьцы } \\
\text { китайцы }\end{array}$ & \\
\hline & \multirow{5}{*}{ MOH } & \multirow{5}{*}{4,677} & 1 & $\begin{array}{l}\text { Зона } \\
\text { приграничного } \\
\text { экономического } \\
\text { сотрудничества } \\
\text { Эренхот - } \\
\text { Замын-Ууд }\end{array}$ & Эренхот & Замын-Ууд & \multirow[t]{4}{*}{$\begin{array}{l}\text { КНР: ханьцы и } \\
\text { монголы } \\
\text { МОН: монголы }\end{array}$} & \multirow{3}{*}{$\begin{array}{l}\text { Пограничный город - } \\
\text { это железнодорожный } \\
\text { порт и крупнейший узел } \\
\text { приграничной торговли между } \\
\text { Монголией и КНР. Когда в } \\
1992 \text { году Эренхот открылся } \\
\text { для международной торговли, } \\
\text { его население увеличилось с } \\
8000 \text { человек до, примерно, } \\
100 \text { о00 человек, включая } \\
\text { трудовых мигрантов. } \\
\text { Как Булган-Такашикен } \\
\text { или Бичигт-Зуун-Хатавч, } \\
\text { существуют и другие границы, } \\
\text { используемые, в основном, } \\
\text { для экспорта минералов } \\
\text { - такие как Ханги-Мандал, } \\
\text { Сумбер-Рашаан, Баянхошу- } \\
\text { Увдуг, Хавиргаа-Аркхашаат и } \\
\text { Гашуун Сухайт-Гантс Мод. }\end{array}$} \\
\hline & & & 2 & $\begin{array}{l}\text { Булган - } \\
\text { Такашикен }\end{array}$ & $\begin{array}{l}\text { Такашикен, } \\
\text { Китай }\end{array}$ & $\begin{array}{l}\text { Булган сум, } \\
\text { Ховдская } \\
\text { область }\end{array}$ & & \\
\hline & & & 3 & $\begin{array}{l}\text { Бичигт Зуун - } \\
\text { Хатавч }\end{array}$ & $\begin{array}{l}\text { Зуун Уземчин } \\
\text { Хошуу, } \\
\text { Силин Гол, } \\
\text { Внутренняя } \\
\text { Монголия }\end{array}$ & $\begin{array}{l}\text { Сум } \\
\text { Эрдэнэцагаан, } \\
\text { провинция Сухэ- } \\
\text { Батор }\end{array}$ & & \\
\hline & & & 4 & $\begin{array}{l}\text { Шевехурен - } \\
\text { Секхи }\end{array}$ & $\begin{array}{l}\text { Эзни, Альшаа, } \\
\text { Внутренняя } \\
\text { Монголия }\end{array}$ & $\begin{array}{l}\text { Гурвантес, } \\
\text { провинция } \\
\text { Умнугови }\end{array}$ & & $\begin{array}{l}\text { Этот пограничный пост закрыт } \\
\text { для туристов и используется } \\
\text { для экспорта угля из Монголии } \\
\text { в КНР. }\end{array}$ \\
\hline & & & 5 & $\begin{array}{l}\text { Самбер - Аркса/ } \\
\text { Аершан }\end{array}$ & $\begin{array}{l}\text { Город Рашаан, } \\
\text { Хянган, } \\
\text { Внутренняя } \\
\text { Монголия }\end{array}$ & $\begin{array}{l}\text { Сум Халхгол, } \\
\text { Дорнодская } \\
\text { область }\end{array}$ & - & - \\
\hline & ПАК & 438 & 1 & $\begin{array}{l}\text { Перевал } \\
\text { Хунджераб }\end{array}$ & Синкиянг & Хунза, Нагар & $\begin{array}{l}\text { КНР: уйгуры } \\
\text { и ханьские } \\
\text { китайцы } \\
\text { ПАК: шины, } \\
\text { яшкуны, } \\
\text { кашмирцы, } \\
\text { кашгарицы, } \\
\text { памирцы, } \\
\text { патанцы и } \\
\text { кохистанцы }\end{array}$ & - \\
\hline & ТАД & 477 & 1 & $\begin{array}{l}\text { Перевал Кульма } \\
\text { (Перевал } \\
\text { Карасу) }\end{array}$ & $\begin{array}{l}\text { Ташкурган- } \\
\text { Таджикский } \\
\text { автономный } \\
\text { уезд, округ } \\
\text { Кашгар, } \\
\text { Синьцзян- } \\
\text { Уйгурский } \\
\text { автономный } \\
\text { район }\end{array}$ & $\begin{array}{l}\text { Мургобский } \\
\text { район, Горно- } \\
\text { Бадахшанская } \\
\text { автономная } \\
\text { область }\end{array}$ & $\begin{array}{l}\text { КНР. Уйгуры } \\
\text { и ханьские } \\
\text { китайцы } \\
\text { К тюркским } \\
\text { народам также } \\
\text { относятся } \\
\text { татары. } \\
\text { ТАД } \\
\text { Таджики }\end{array}$ & - \\
\hline
\end{tabular}

продолжено на следующей странице 
Продолжение Таблицы в Приложении 3

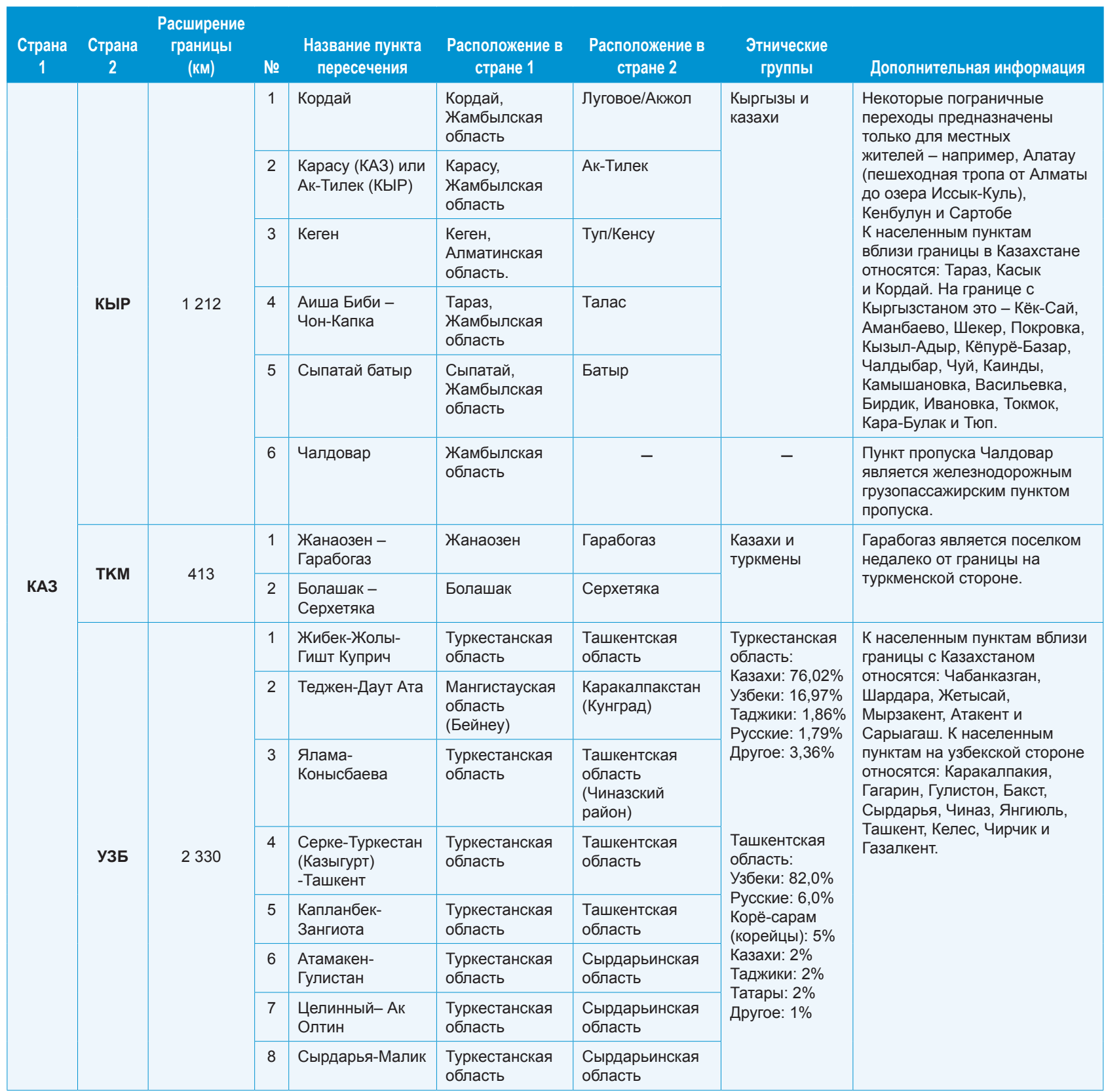


Продолжение Таблицы в Приложении 3

\begin{tabular}{|c|c|c|c|c|c|c|c|c|}
\hline $\begin{array}{c}\text { Страна } \\
1\end{array}$ & $\begin{array}{l}\text { Страна } \\
2\end{array}$ & $\begin{array}{l}\text { Расширение } \\
\text { границыы } \\
\text { (км) }\end{array}$ & № & $\begin{array}{c}\text { Название пункта } \\
\text { пересечения }\end{array}$ & $\begin{array}{l}\text { Расположение в } \\
\text { стране } 1\end{array}$ & $\begin{array}{l}\text { Расположение в } \\
\text { стране } 2\end{array}$ & $\begin{array}{l}\text { Этнические } \\
\text { группы }\end{array}$ & Дополнительная информация \\
\hline \multirow{15}{*}{ КЫР } & \multirow{5}{*}{ ТАД } & \multirow{5}{*}{984} & 1 & Баткен - Исфрара & Баткен & Исфрара & - & \multirow{5}{*}{$\begin{array}{l}\text { К приграничным поселениям } \\
\text { со стороны Кыргызской } \\
\text { Республики относятся: Баткен, } \\
\text { Самаркандык, Центральный, } \\
\text { Кулунду, Сулюкта, Самат, } \\
\text { Ак-Суу, Кёк-Таш, Кара-Тейит, } \\
\text { Карамык и Бор-Добе. К } \\
\text { приграничным поселениям } \\
\text { со стороны Таджикистана } \\
\text { относятся: Лаккон, Кулькент, } \\
\text { Навгилем, Исфара, Сурх, } \\
\text { Чорку, Шураб, Кистакуз, } \\
\text { Гафуров, Пролетарск, Муджум, } \\
\text { Дахкат и Росровут. }\end{array}$} \\
\hline & & & 2 & $\begin{array}{l}\text { Кулунду - Овчи } \\
\text { Калача }\end{array}$ & Кулунду & Овчи Калача & - & \\
\hline & & & 3 & $\begin{array}{l}\text { Маданият - } \\
\text { Маданияй }\end{array}$ & Маданият & Маданияй & - & \\
\hline & & & 4 & $\begin{array}{l}\text { Карамык - } \\
\text { Дароот Корган }\end{array}$ & Карамык & Дарут Корган & - & \\
\hline & & & 5 & $\begin{array}{l}\text { Бор-Доба - } \\
\text { Кызыларт }\end{array}$ & Бор-Доба & Кызыларт & - & \\
\hline & \multirow{10}{*}{ УзБ } & \multirow{10}{*}{1314} & 1 & Достык-Достлик & $\begin{array}{l}\text { Ошская } \\
\text { область }\end{array}$ & $\begin{array}{l}\text { Андижанская } \\
\text { область }\end{array}$ & \multirow{10}{*}{$\begin{array}{l}\text { Более } \\
\text { половины } \\
\text { всех узбеков } \\
\text { Кыргызстана } \\
\text { проживают } \\
\text { в Ошской } \\
\text { области - 28\% } \\
\text { населения } \\
\text { области. }\end{array}$} & \multirow{10}{*}{$\begin{array}{l}\text { К населенным пунктам у } \\
\text { границы с Кыргызстаном } \\
\text { относятся: Кёк-Таш, Сумсар, } \\
\text { Ала-Бука, Аккоргон, Ак- } \\
\text { Там, Туюкджар, Кербен, } \\
\text { Успенковка, Кызыл-Джар, } \\
\text { Шамалды-Сай, Кочкор-Ата, } \\
\text { Джалал-Абад, Кара-Суу, Ош, } \\
\text { Араван, Уч-Коргон, Кызыл-Кия, } \\
\text { Кадамжай, Пулгон и Зар-Таш. } \\
\text { Рядом с Узбекистаном к } \\
\text { ним относятся Гава, Варзик, } \\
\text { Косонсой, Искават, Заркент, } \\
\text { Парамат, Бековат, Янгикурган, } \\
\text { Учкурган, Пайтуг, Андижан, } \\
\text { Пахтаобод, Дардак, Ханабад, } \\
\text { Корасув, Кургантепе, Асака } \\
\text { (Узбекистан), Палванташ, } \\
\text { Мархамат, Кува, Фергана, } \\
\text { Кувасой, Маргилан и Риштон. }\end{array}$} \\
\hline & & & 2 & $\begin{array}{l}\text { Бекабад- } \\
\text { Ханобад }\end{array}$ & $\begin{array}{l}\text { Джалал- } \\
\text { Абадская } \\
\text { область }\end{array}$ & $\begin{array}{l}\text { Андижанская } \\
\text { область }\end{array}$ & & \\
\hline & & & 3 & $\begin{array}{l}\text { Маданият- } \\
\text { Маданият }\end{array}$ & $\begin{array}{l}\text { Джалал- } \\
\text { Абадская } \\
\text { область }\end{array}$ & $\begin{array}{l}\text { Андижанская } \\
\text { область }\end{array}$ & & \\
\hline & & & 4 & $\begin{array}{l}\text { Кызыл-Кия - } \\
\text { Узбекистан }\end{array}$ & $\begin{array}{l}\text { Баткенская } \\
\text { область }\end{array}$ & $\begin{array}{l}\text { Ферганская } \\
\text { область }\end{array}$ & & \\
\hline & & & 5 & Кенсай-Учкурган & $\begin{array}{l}\text { Джалал- } \\
\text { Абадская } \\
\text { область }\end{array}$ & $\begin{array}{l}\text { Наманганская } \\
\text { область }\end{array}$ & & \\
\hline & & & 6 & $\begin{array}{l}\text { Кара-Багиш - } \\
\text { Мингтепа }\end{array}$ & $\begin{array}{l}\text { Ошская } \\
\text { область }\end{array}$ & $\begin{array}{l}\text { Андижанская } \\
\text { область }\end{array}$ & & \\
\hline & & & 7 & Баймак-Касансой & $\begin{array}{l}\text { Джалал- } \\
\text { Абадская } \\
\text { область }\end{array}$ & $\begin{array}{l}\text { Наманганская } \\
\text { область }\end{array}$ & & \\
\hline & & & 8 & $\begin{array}{l}\text { Сейдукум- } \\
\text { Пушмон }\end{array}$ & $\begin{array}{l}\text { Джалал- } \\
\text { Абадская } \\
\text { область }\end{array}$ & $\begin{array}{l}\text { Андижанская } \\
\text { область }\end{array}$ & & \\
\hline & & & 9 & $\begin{array}{l}\text { Интимак- } \\
\text { Кеаканер }\end{array}$ & $\begin{array}{l}\text { Ошская } \\
\text { область }\end{array}$ & $\begin{array}{l}\text { Андижанская } \\
\text { область }\end{array}$ & & \\
\hline & & & 10 & $\begin{array}{l}\text { Сумсар- } \\
\text { Каракурган }\end{array}$ & $\begin{array}{l}\text { Джалал- } \\
\text { Абадская } \\
\text { область }\end{array}$ & $\begin{array}{l}\text { Наманганская } \\
\text { область }\end{array}$ & & \\
\hline
\end{tabular}


Продолжение Таблицы в Приложении 3

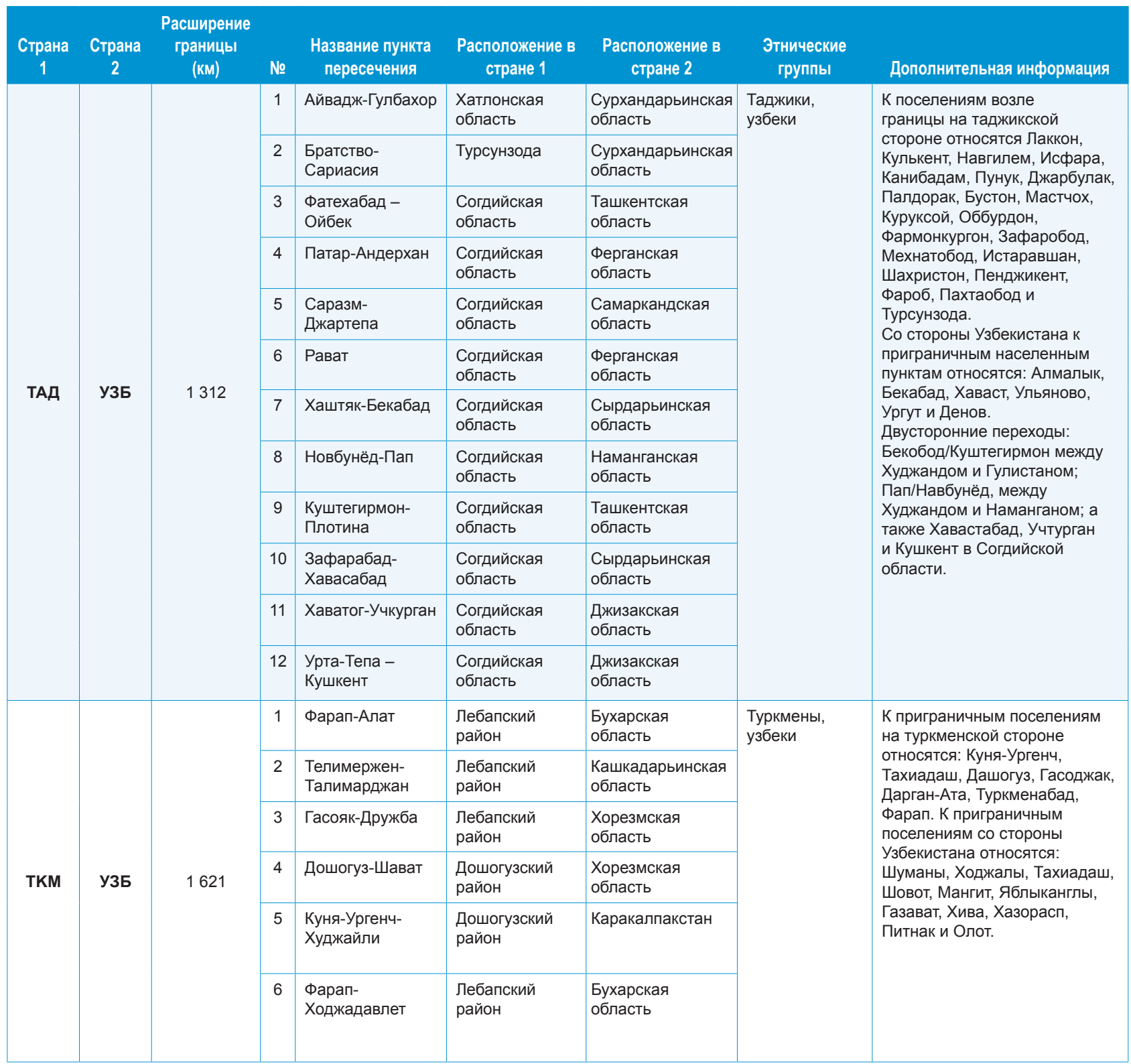

АФГ = Афганистан, АЗЕ = Азербайджан, КНР = Китайская Народная Республика, ГРУ = Грузия, КАЗ = Казахстан,

КЫР = Кыргызская Республика, км = километр, МОН = Монголия, ПАК = Пакистан, ТАД = Таджикистан, ТКМ = Туркменистан, УЗБ = Узбекистан

Примечание. Страны выстроены в алфавитном порядке и каждая граница отображается только один раз.

а Д. Триллинг. 2014 г. На китайско-казахстанской границе находится однобокая зона свободной торговли. Eurasianet. 5 сентября.

b Организация Объединенных Наций по вопросам образования, науки и культуры. Программа «Шелковый путь»: Кашгар.

Источник: Секретариат ЦАРЭС. 


\section{Библиография}

И. Абдуллаев, Д. Казбеков, Г, Мантритилаке и К. Джумабоев. 2009 г. Группы водопользователей в Центральной Азии: новая форма коллективных действий в управлении оросительной водой. Управление водными ресурсами. 24 (5). стр. 1029-1043.

Центр афганских исследований. Серия диалогов пакистанско-афранской молодежи.

Азиатский банк развития (АБР). 2017 г. ЦАРЭС 2030: Соединяя регион для совместного и устойчивого развития. Манила.

2019 г. Образование и профессиональное обучение в рамках программы ЦАРЭС: Предварительное исследование. Манила.

2019 г. Содействие региональному сотрудничеству в сфере туризма в рамках ЦАРЭС 2030: Предварительное исследование. Манила.

—. Проект Гендерной стратегии ЦАРЭС до 2030 г. Не опубликовано.

CGTN. 2018 г. Прослеживая древний Шелковый путь: Уланкаб: Новое будущее старых караван-сараев. 4 октября.

Дж. Чаппелоу. 2020 г. Евразийский экономический союз (ЕАЭС). Инвестопедия. 18 сентября.

Йи Чен. 2018 г. Инвестиционная конкуренция Китая и Японии в Монголии. The Diplomat. 1 августа.

China Daily. 2014 г. Китай и Монголия переходят к всеобъемлющему стратегическому партнерству. 21 августа.

China Daily. 2019 г. В Уланчабе открылась выставка культурного туризма «Чайный путь». 24 июня.

И. Чириса, О. С. Дирваи и А. Мумба. 2014 г. Обзор эволюции и траектории Афрриканского союза как инструмента региональной интеграции. SpringerPlus. 2014 г. (3). стр. 101-114.

Г. Коккосис и П. Нийкамп. 2012 г. Преодоление изоляции: информационные и транспортные сети в стратегиях развития перифрерийных территорий. Публикация в издании "Достижения пространственной науки» (Advances in Spatial Science). Springer Science \& Business Media. стр. 55. 
С. Э. Корнелл и С. Ф. Старр. 2018 г. Региональное сотрудничество в Центральной Азии: актуальность моделей мира. Аналитик по Центральной Азии и Кавказу. 4 декабря.

Deutsche Gesellschaft für Internationale Zusammenarbeit (GIZ). Программа территориального сотрудничества в рамках восточного партнерства в контексте программы местного управления: Южный Кавказ.

Программа территориального сотрудничества в рамках восточного партнерства (ЕАРТC). 2018 г. Совместная операционная программа Азербайджан-Грузия.

EAРТС. 2018 г. Программа поддержки территориального сотрудничества в рамках восточного партнерства.

Сеть свободных и честных выборов. 2019 г. Мирные, хорошо организованные выборы в недавно объединенных округах ознаменовали завершение конституционного слияния.

И. Гасанлы. 2018 г. Страновой отчет: Границы Азербайджана. Центр национальных и международных исследований.

Н. Какубава и Т. Чинчараули. 2010 г. Ірансграничное сотрудничество: Практическое руководство. Ассоциация молодых экономистов Грузии.

А. Маккей. 2008 г. Управление границами и гендерная проблематика. В публикации под редакцией Меган Бастик и Кристин Валасек. Пособие по рефоорме сектора гендерной проблематики и безопасности. Женева: DCAF, ОБСЕ/БДИПЧ, Международный учебный и научно-исследовательский институт по улучшению положения женщин (МУНИУЖ) $\mathrm{OOH}$.

А. Мэтьюз. 2003 г. Региональная интеграция в Африке. В публикации «Региональная интеграция и продовольственная безопасность в развивающихся странах». Продовольственная и сельскохозяйственная организация Объединенных Наций. Рим.

Э. Медейрос. 2018 г. «Европейское территориальное сотрудничество: теоретические и эмпирические подходы $к$ процессу $и$ последствиям приграничного и транснационального сотрудничества в Европе». Издательство «Springer International Publishing».

А. Морел. 2020 г. Пограничные районы Афрганистана: непослушные, неуправляемые и необходимые для мира. Фонд Азии. 22 января.

Бизнес в России сегодня. 2019 г. Россия расширяет туристические связи с Китаем и Монголией. 24 июня.

Информация о шенгенской визе. Шенгенская зона.

М. Слюсарчук. 2013 г. Модели партнерства и сотрудничества в приграничных регионах. AUDCE. 9 (4). стр. 267-280. 
УмотбайуулуД. 2018г.Деньнакрупнейшемрынке Ферганскойдолины. Центральноазиатское бюро аналитической отчетности. 17 октября.

Программа развития ООН (ПРООН). Управление границами в Северном Афрганистане II (BOMNAF II).

. Строительство пограничного пункта пропуска Красный мост между Грузией и Азербайджаном.

ООН-Женщины. 2017 г. Женщины создают мир на кыргызско-таджикской гранище. Истории. 2 фревраля.

Университет Центральной Азии. 2019 г. Кыргызская Республика. Семинар «Текущая динамика приграничных территорий в Ферганской долине». 14 фревраля.

Х. С. Уоррен, М. Люнгман и Э. Янг. 2019 г. Каково это - женщинам торговать через границу? Блог Всемирного банка. 3 июня.

Фрауке де Вейер. 2017 г. ㅇбор приграничного сотрудничества ФМС в интересах устойчивого мира и развития. Фонд PeaceNexus.

К. Уилтон-Стир. 2018г. Воссоединение афрганского и таджикского Бадахшана: экономическое развитие в приграничном регионе. Фонд Ага Хана, Великобритания. 19 декабря.

Всемирный банк. 2018 г. Йнформационный документ о проекте/Комплексный перечень данных по гарантиям: Процветающие села Узбекистана. 10 сентября.

Всемирный банк. 2019 г. Проект развития сельских предприятий Ферганской долины.

Всемирный экономический форум. 2019 г. Изменение климата угрожает безопасности в Центральной Азии. Вот способы снизить риск. 25 января.

Xinhuanet. 2019 г. Подборка фрактов: новый прогресс в реализации инициативы «Один пояс, один путь». 19 марта.

Xinhuanet. 2020 г. Объем торговли между Монголией и Китаем в 2019 году достиг 8,9 млрд долларов США. 26 января.

Х. Чжэ. 2019 г. Совещание Китая, России и Монголии по вопросам укрепления трехсторонних туристических связей.

Р. Чжоу. 2019 г. Монгольское меньшинство. China Highlights. 17 января. 


\section{Усиление трансграничного сотрудничества сообществ в регионе ЦАРЭС}

Обзорное исследование

Страны-участницы Центральноазиатского регионального экономического сотрудничества (ЦАРЭС) сталкиваются с множеством общих экономических, социальных и экологических проблем, которые напрямую влияют на их граждан и сообщества. Сообщества, живущие в приграничных регионах, сталкиваются с такими проблемами уникальным образом благодаря историческим и культурным связям, общим ресурсам и географическому положению, системам социальной поддержки, включая семью и друзей, а также ведение бизнеса и источники средств к существованию. В этом отчете представлен краткий анализ сильных и слабых сторон, возможностей и угроз (SWOT) ЦАРЭС для усиления развития трансграничных сообществ. В нем определен ряд рекомендаций для того, чтобы ЦАРЭС играла инициативную роль в расширении приграничного сотрудничества в приграничных регионах.

\section{О Программе Центральноазиатского регионального экономического сотрудничества}

ЦАРЭС представляет собой партнерство 11 стран - Афганистана, Азербайджана, Китайской Народной Республики, Грузии, Казахстана, Кыргызской Республики, Монголии, Пакистана, Таджикистана, Туркменистана и Узбекистана - и партнеров по развитию, совместно работающих над продвижением развития через сотрудничество в целях ускорения экономического роста и сокращения бедности.

\section{Об Азиатском банке развития}

АБР стремится к достижению процветания, всеохватности, стабильности и устойчивости в Азии и Тихоокеанском регионе, непрестанно направляя усилия на искоренение крайней нищеты. Основанный в 1966 году банк принадлежит 68 членам, 49 из которых относятся к данному региону. Его основными инструментами оказания помощи развивающимся странам-членам являются диалог по вопросам проводимой политики, кредиты, инвестиции в акционерный капитал, гарантии, гранты и техническая помощь.
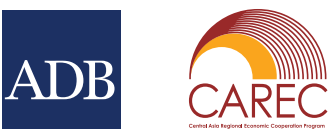

\section{Секретариат ЦАРЭС}

www.carecprogram.org

\section{АЗИАТСКИЙ БАНК РАЗВИТИЯ}

6 ADB Avenue, Mandaluyong City 1550 Metro Manila, Philippines

www.adb.org 